GSA Data Repository 2016177

\title{
$\mathrm{U}-\mathrm{Pb}$ geochronology of calcite-mineralized faults: Absolute timing of rift- related fault events on the northeast Atlantic margin
}

\author{
Nick M W Roberts \& Richard J Walker
}

\section{U-Pb method}

$\mathrm{U}-\mathrm{Pb}$ geochronology via the in-situ Laser Ablation Inductively Coupled Mass Spectrometer (LA-ICPMS) method was conducted at the Geochronology \& Tracers Facility, NERC Isotope Geosciences Laboratory (Nottingham, UK). The method utilises a New Wave Research 193UC excimer laser ablation system, coupled to a Nu Instruments Attom single-collector sector-field ICP-MS. The carbonate method (Li et al., 2014; Coogan et al., 2016) is adapted from that used for zircon (see Spencer et al., 2014), with some modifications.

Standard sample bracketing utilises NIST 614 glass for normalisation of ${ }^{207} \mathrm{~Pb} /{ }^{206} \mathrm{~Pb}$ ratios (Woodhead \& Hergt, 2007). After correction of ${ }^{207} \mathrm{~Pb} /{ }^{206} \mathrm{~Pb}$ ratios, an in-house carbonate reference material (WC1) of known age ( $254 \pm 7 \mathrm{Ma}$; in-house isotope dilution $\mathrm{U}-\mathrm{Pb}$ data) is used for normalisation of ${ }^{206} \mathrm{~Pb} /{ }^{238} \mathrm{U}$ ratios (Figure 1). No downhole correction is made, instead the mean of each $30 \mathrm{~s}$ ablation (excluding the first $2 \mathrm{~s}$ of data) is used. Normalisation is based on the measured/accepted ratio derived from the session-based drift-corrected mean of the primary WC-1 reference material. Each session refers to a morning or afternoon, i.e. 2-3 hours of analyses. Data are not corrected for common lead. Those ages that are deemed robust (based on low MSWD), are determined from lower intercepts on a Tera-Wasserburg (i.e. total $\mathrm{Pb} / \mathrm{U}$ isochron) plot. All samples show highly variable $\mathrm{U} / \mathrm{Pb}$ ratios, and mixing between common lead $\left({ }^{207} \mathrm{~Pb} /{ }^{206} \mathrm{~Pb}=\sim 0.89\right)$ and radiogenic lead components. Some samples are deemed unsuccessful; they are either dominated by common lead, or reveal highly scattered analyses. All of these have very low U contents, near or below detection limits. No samples revealed precise analyses (i.e. high $\mathrm{U}$ and $\mathrm{Pb}$ counts), and scattered regressions, as may be expected of samples with strong open-system behaviour. One sample, GOT-1-1, had few radiogenic analyses compared to the dominant common lead component, and with further work may have revealed a young $\sim 19 \mathrm{Ma}$ age.

The robustness of this method was discussed by Li et al. (2014), who showed that ages determined by LA-ICP-MS and normalised to WC-1 were overlapping with those determined by isotope dilution. Additionally, we present repeat analyses here from different instrumentation, and/or different analytical sessions. For data run on different instruments with different samples, or run in different sessions using the same material, the resulting ages are within uncertainty of each other (Figure 2). No secondary reference material with known age and homogeneous composition was available to be run during each analytical session.

Laser parameters are: $100 \mu \mathrm{m}$ spot, $10 \mathrm{~Hz}, \sim 7-8 \mathrm{j} . \mathrm{cm}^{2}$ fluence, and 30 second ablation. Material is preablated to clean the sample site with $150 \mu \mathrm{m}$ spots for 4 seconds.

The reproducibility of the primary WC-1 reference material is around $2-4 \%$ per session. An estimate of the session reproducibility is propagated (as excess variance) onto the sample data. The ages quoted have additional systematic uncertainties propagated onto the final age, these include decay constant uncertainties, the laboratory-based long-term reproducibility of the method $(\sim 2 \%)$ and the uncertainty on the reference material age $(\sim 3.75 \%$; based on in-house isotope dilution measurements). 


\section{Trace element mapping}

Samples were screened with a combination of spot traverses and/or maps (produced by combining line rasters). Line raster data were reduced and maps created using the software Iolite 2.3 . ${ }^{44} \mathrm{Ca}$ was used as an internal standard, and NIST614 was used to normalise the concentration data according to Jochum et al. (2011). Line rasters employed a $100 \mu \mathrm{m} * 100 \mu \mathrm{m}$ square, travelling at $50 \mu \mathrm{m} / \mathrm{second}$.

Figure 1: Analyses of WC-1 calcite reference material from all analytical sessions that sample data were obtained.

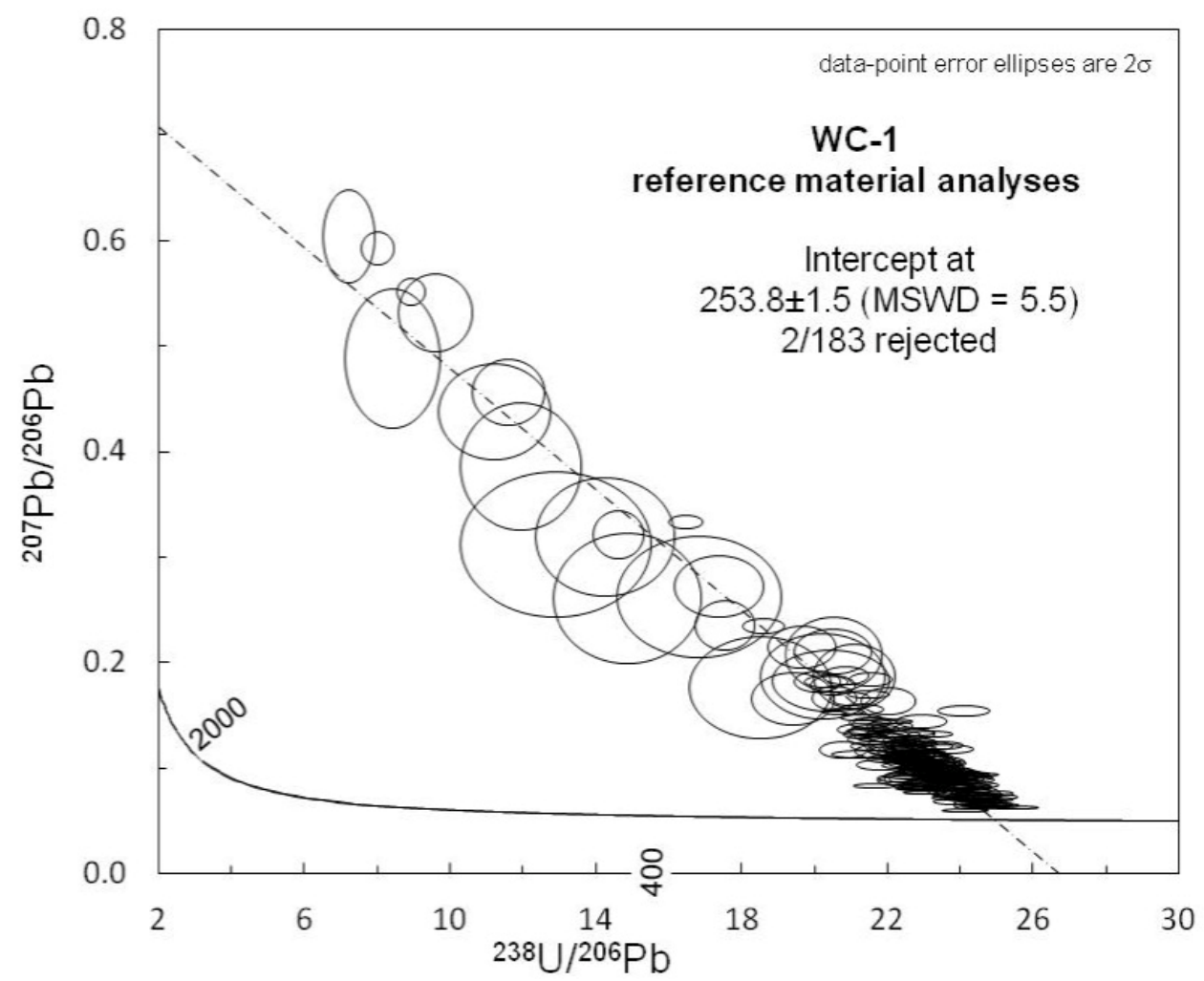


Figure 2: U-Pb data from samples run in different sessions to show the reproducibility of results.
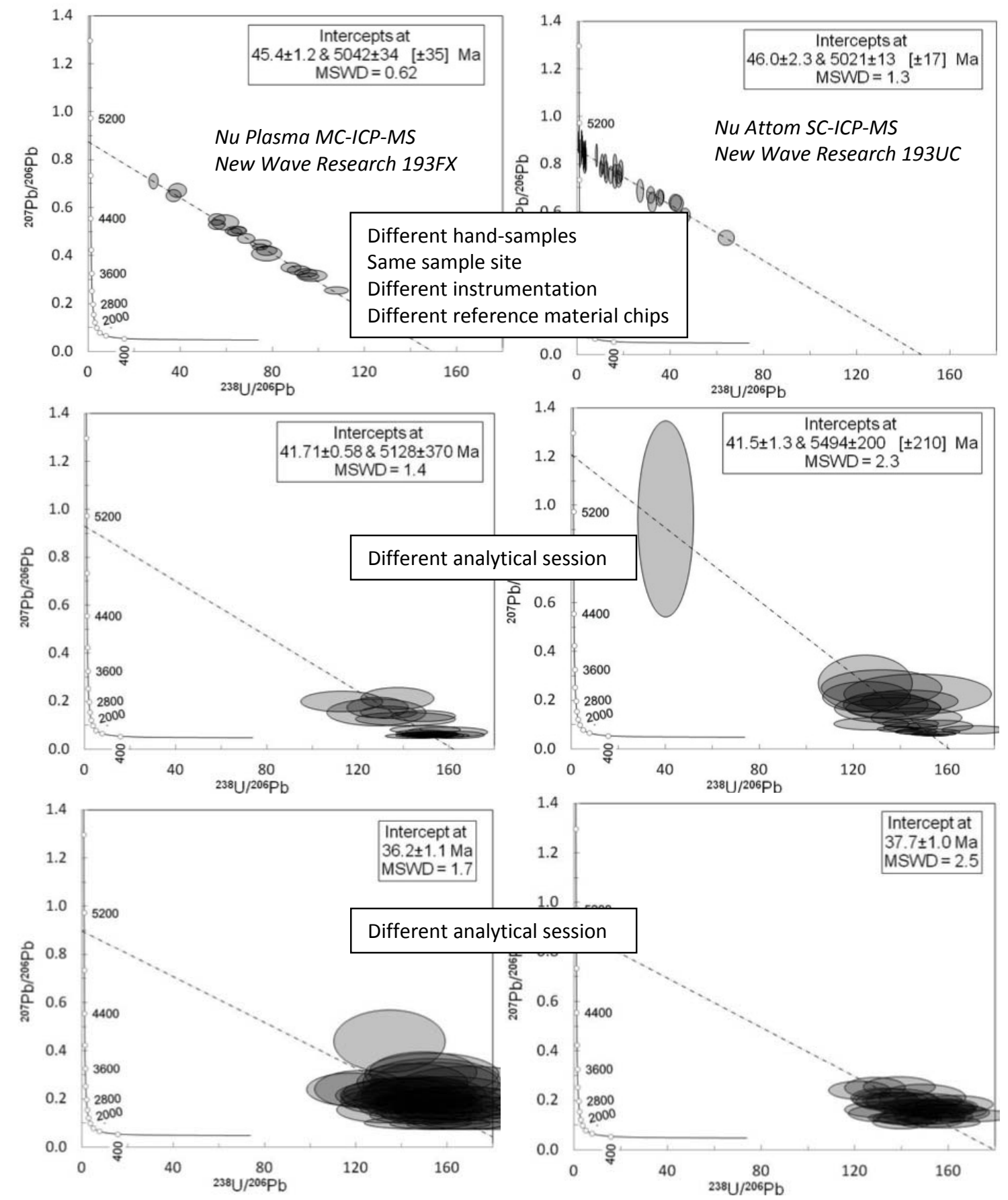

cal session

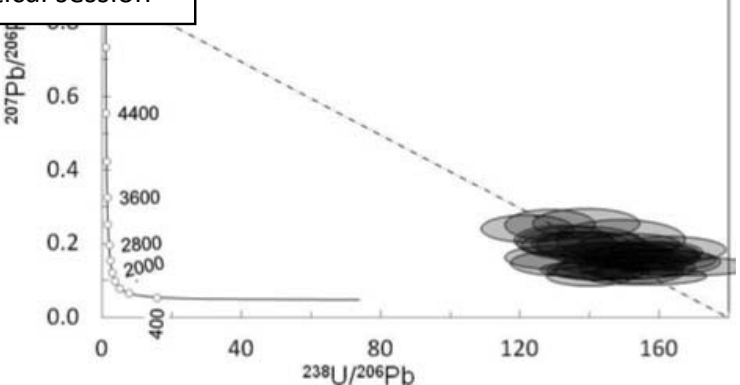

Supplementary Table 


\section{Sample Characterisation}

'Successful' U-Pb dates'

\section{LEY-2-1}

\section{Fault:}

Set 2

Strike: WNW-ESE

Unknown displacement.

Apparent opening mode vein with complex crack-seal vein system forming fault core zone (see supplementary figure LEY samples: E-F), and peripheral veins forming damage zone (up to $50 \mathrm{~cm}$ from fault core). Fault core and damage zone hosts calcite veins with zeolite overgrowth (1-2 mm thick), suggesting incomplete mineral filling during calcite precipitation. Fault records several stages of fault formation as demonstrated by cross-cutting calcite and zeolite veins in fault core. It is important to note that the hosting fault is adjacent to a NE-SW-striking Set 3 fault of unknown displacement (see Fig 4. in main text).

\section{Vein sample:}

Complex crack-seal vein, showing syntaxial calcite growth with minor zeolite along host-rock margins. Dated material is from edge of fault zone, with crack-seal calcite that is blocky and equant. Vein margins are non-uniform-planar consistent with segmented fault growth and multiple fracture events leading to linkage..

\section{Composition:}

Elemental mapping shows consistent distribution pattern amongst all elements, but a pattern that is not clearly linked to primary growth zonation.
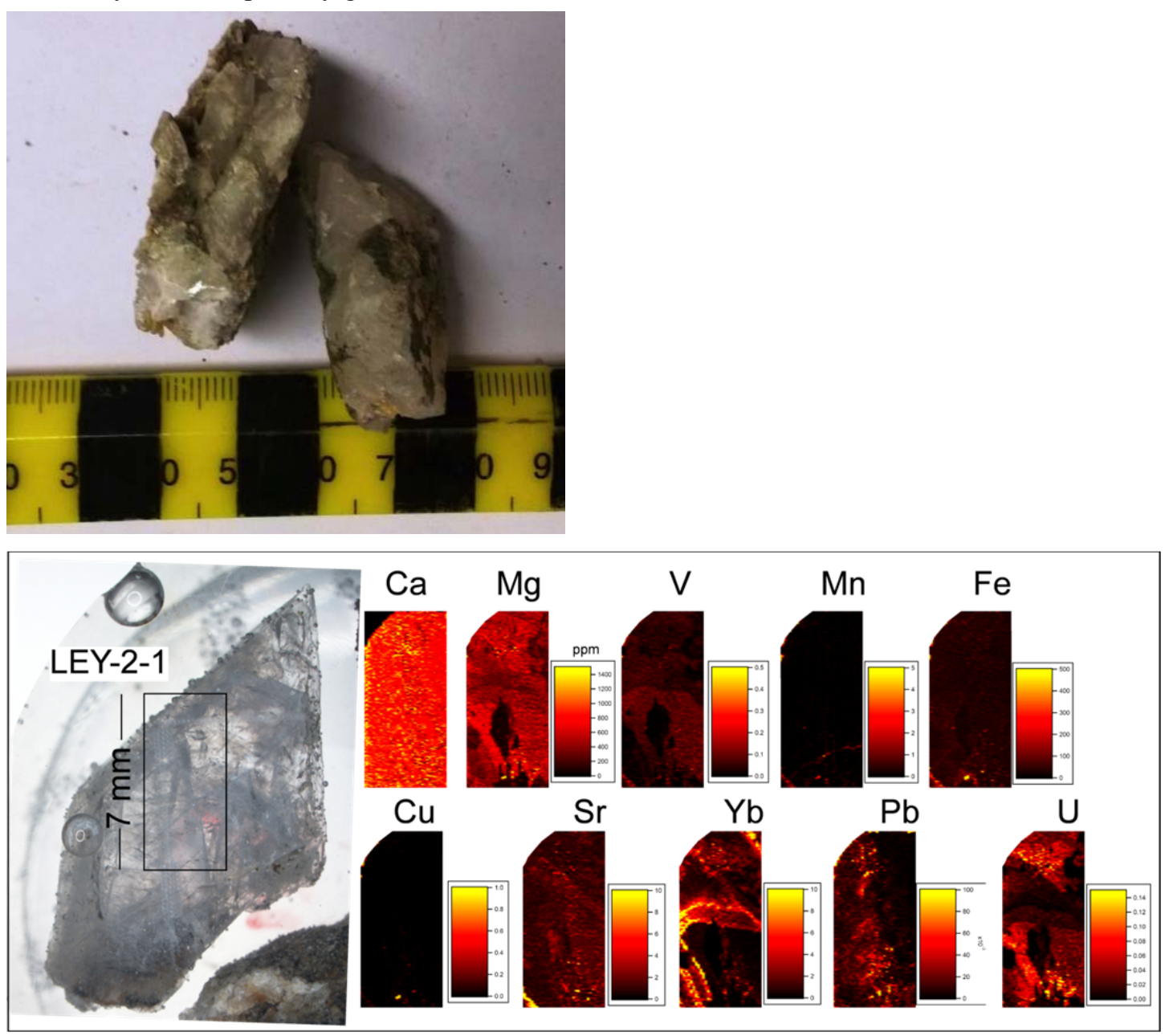
MOL-1-1

Fault:

Set 2

Strike: ENE-WSW

$\sim 4-5 \mathrm{~m}$ displacement (dextral oblique) accommodated across a $0.1 \mathrm{~m}$ to $2.0 \mathrm{~m}$ fault core and damage zone, which varies in thickness and fault rock type depending on the host lithology: basaltic units disaggregate to form breccias; volcaniclastic units are dragged into the master fault plane forming discrete extension and extensional-shear veins. Fault damage varies both along strike and up/down dip of the master fault, becoming much thinner through the volcaniclastic horizon. Brecciated calcite in veins indicates multiple slip events accommodated across the fault zone.

\section{Vein sample:}

Hosted in volcaniclastic sediments.

Crack-seal vein with syntaxial zeolite margins, to calcite centre.

Most veins are 1-10 mm thick, and comprise fibrous zeolite.

Some blocky calcite within zeolite filled veins, occurring as small crystals $<2 \mathrm{~mm}$.

\section{Composition:}

Formed as mixed zeolite and calcite growth, so difficult to determine zonation within calcite and the nature of individual calcite crystals within the scale of this study.
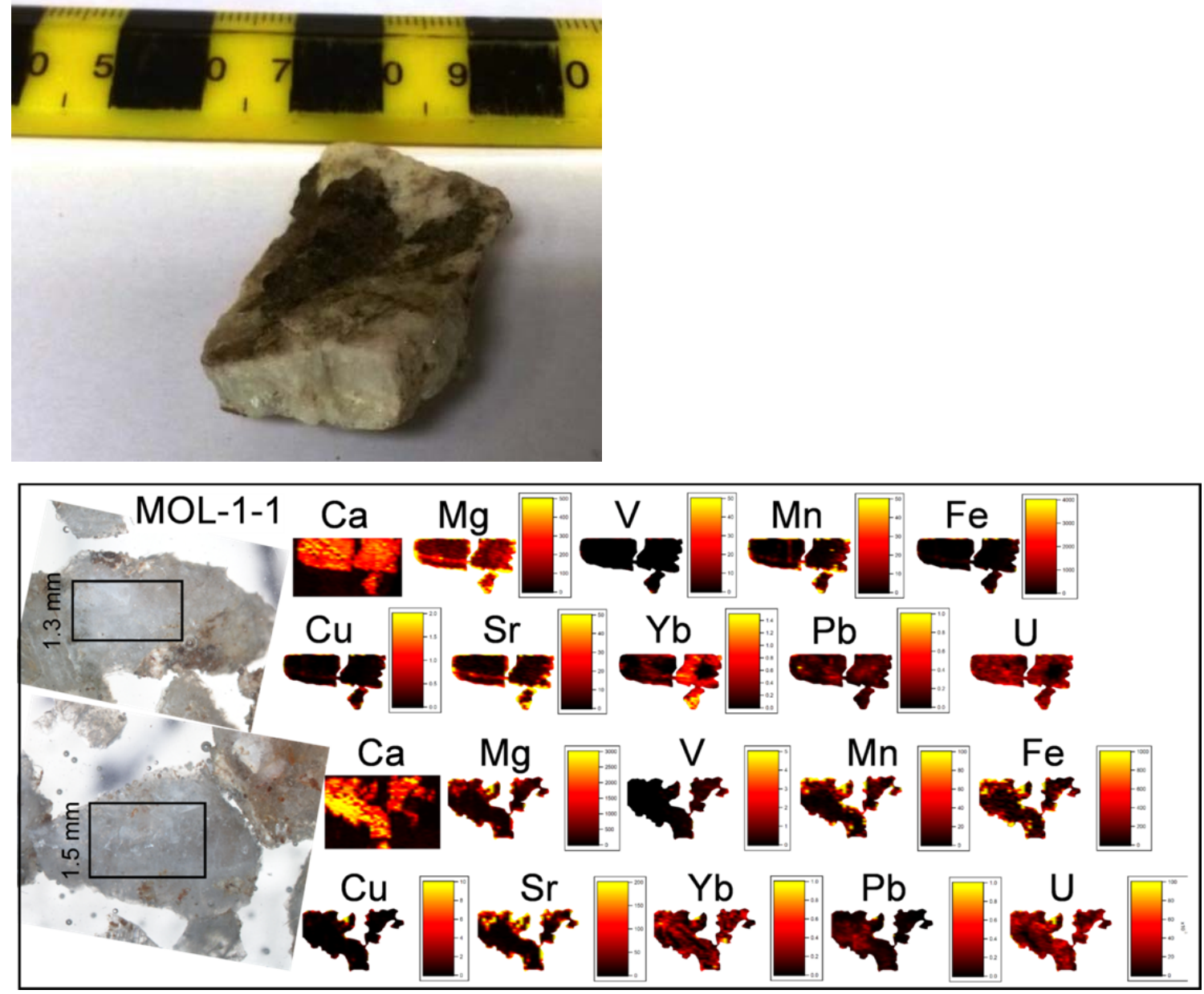
MOL-1-2

Fault:

Set 2

Strike: ENE-WSW (same fault as Mol-1-1)

\section{Vein sample:}

Hosted in basalt lava

Single-stage crack-seal vein with syntaxial, possibly stretched vein calcite growth.

Blocky calcite that is fine-grained mostly, few larger crystals filling the width of vein.

\section{Composition:}

Distribution of uranium matches other elements in its pattern; however, the calcite itself is intergrown with some fine-grained zeolite, making the growth zonation difficult to determine.

Optically, some larger $(>5 \mathrm{~mm})$ calcite crystals look pristine.
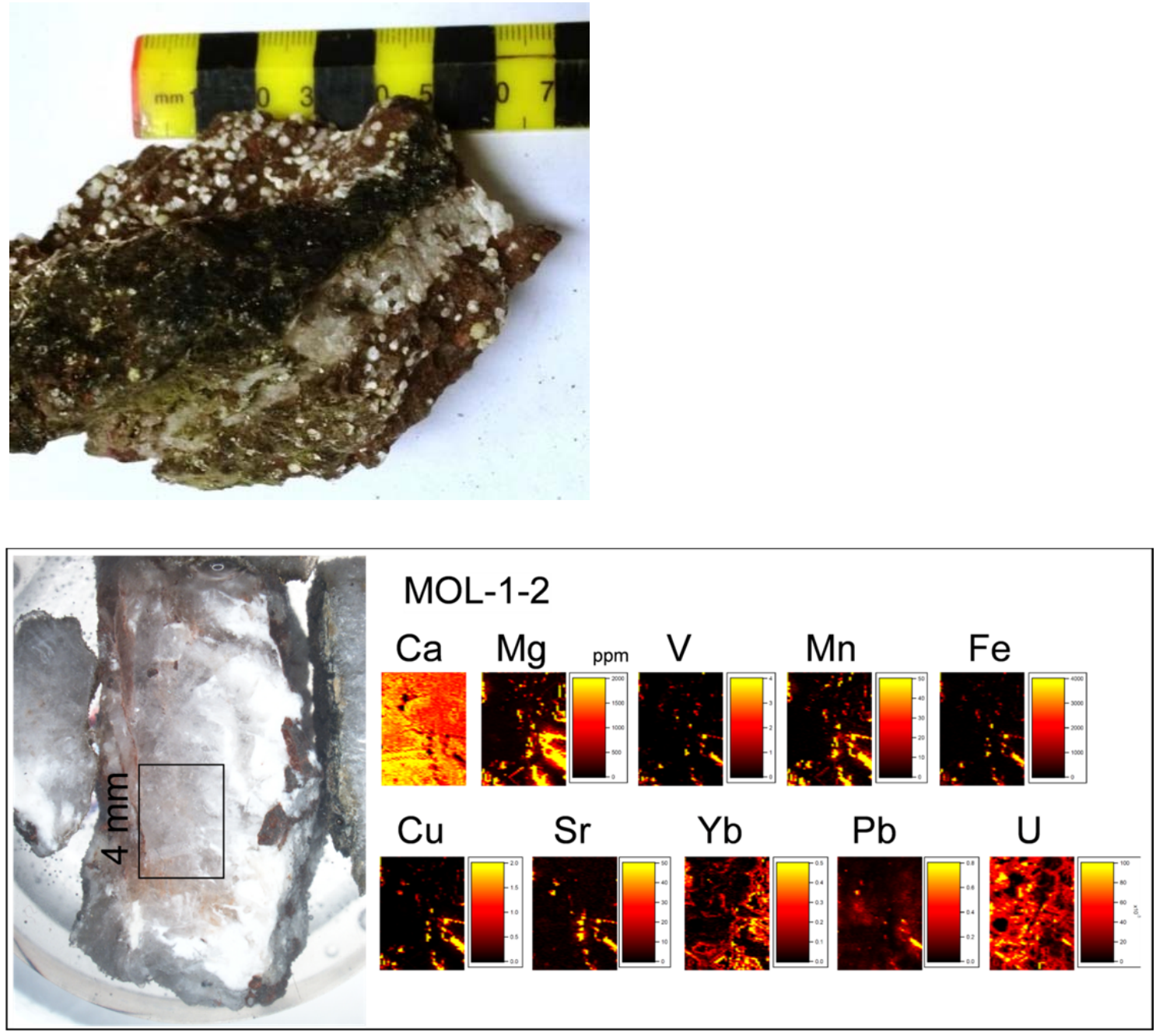


\section{TJN-0-1}

\section{Fault:}

Set 2

Strike: ENE-WSW

Dextral strike-slip, unknown displacement. Fault zone ranges from $\sim 1.0-3.0 \mathrm{~m}$ thick displaying crack seal veins parallel to the main fault zone. Veins are typically $1-2 \mathrm{~cm}$ thick, but locally total vein thickness is up to $\sim 30 \mathrm{~cm}$ thick, comprising multiple crack seal type veins and breccia zones. Wall rock contained within veins indicate stage opening of fractures, which linked to form through-going faults.

\section{Vein sample:}

Crack-seal syntaxial zeolite (fibrous), overgrown by syntaxial blocky calcite (up to $1 \mathrm{~cm}$ size). Fragments of country rock within vein (i.e. brecciation during faulting), with symmetric growth to vein walls. Core of vein is a chaotic breccia that may represent infill or implosion.

Dated calcite is from growth zone closest to host margin (northern margin).

\section{Composition:}

The dated material is blocky calcite forming the first calcite zone after zeolite grown onto the host margin. Mapping shows clear well-preserved growth banding in all elements (except $\mathrm{Pb}$ which is very low in concentration). The direction of growth is perpendicular to the host margin.
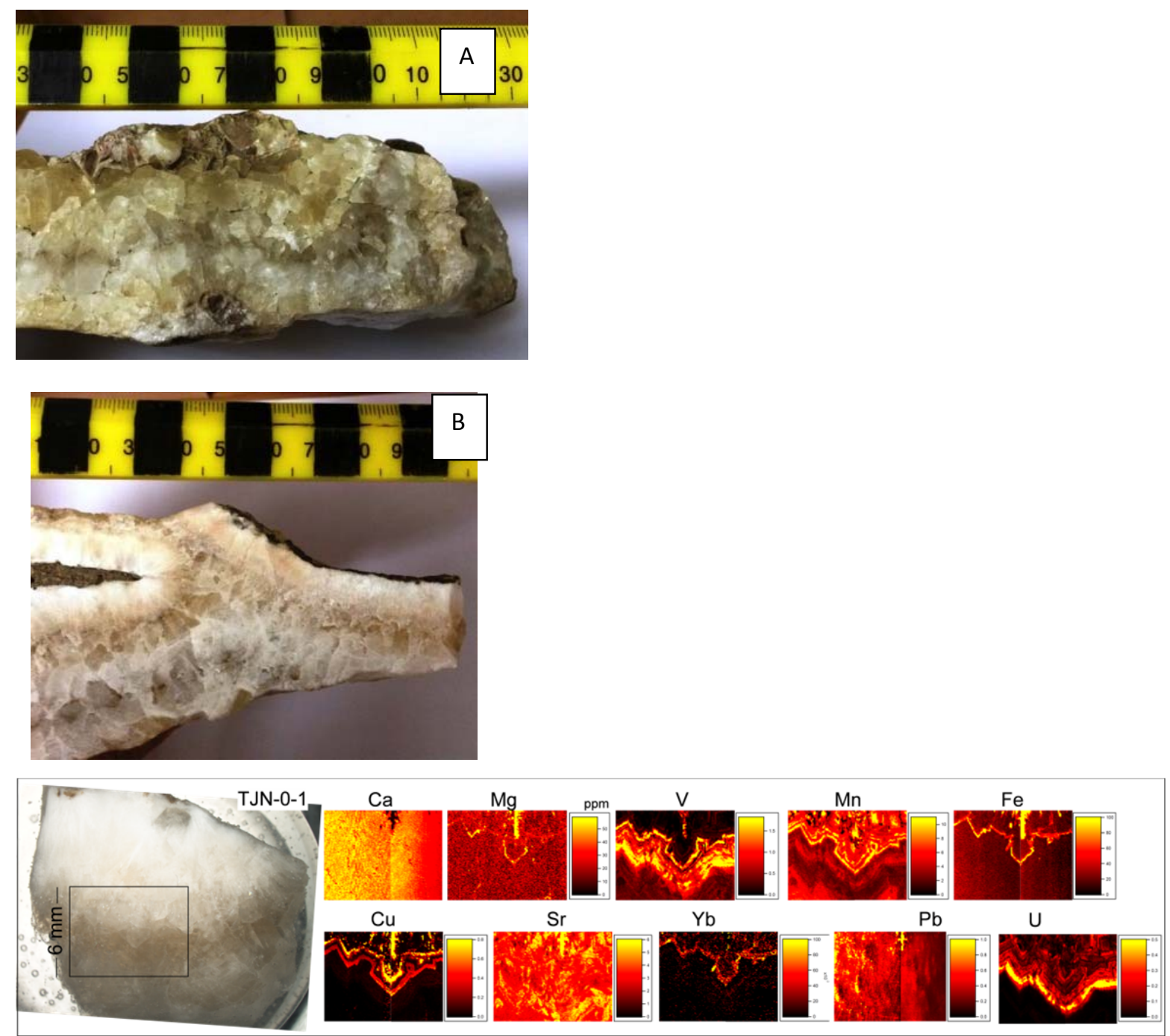
TJN-1-3

Fault:

Set 2

Strike: ESE-WNW

Sinistral oblique slip, unknown displacement; sub-parallel to, and cuts dike. Fault zone is up to $2 \mathrm{~m}$ thick, comprising fracture mesh damage zone and locally brecciated fault core. Crack seal veins line the fault core and locally form part of the central breccia. Central breccia hosts euhedral calcite, and zeolite on calcite crystal faces.

\section{Vein sample:}

Implosion breccia.

Zeolite intergrown with calcite and host rock fragments.

Calcite is blocky and equant and up to $3 \mathrm{~mm}$ in size.

\section{Composition:}

The concentration of most elements is very low and below or near detection limits. The distribution is thus hard to discern.
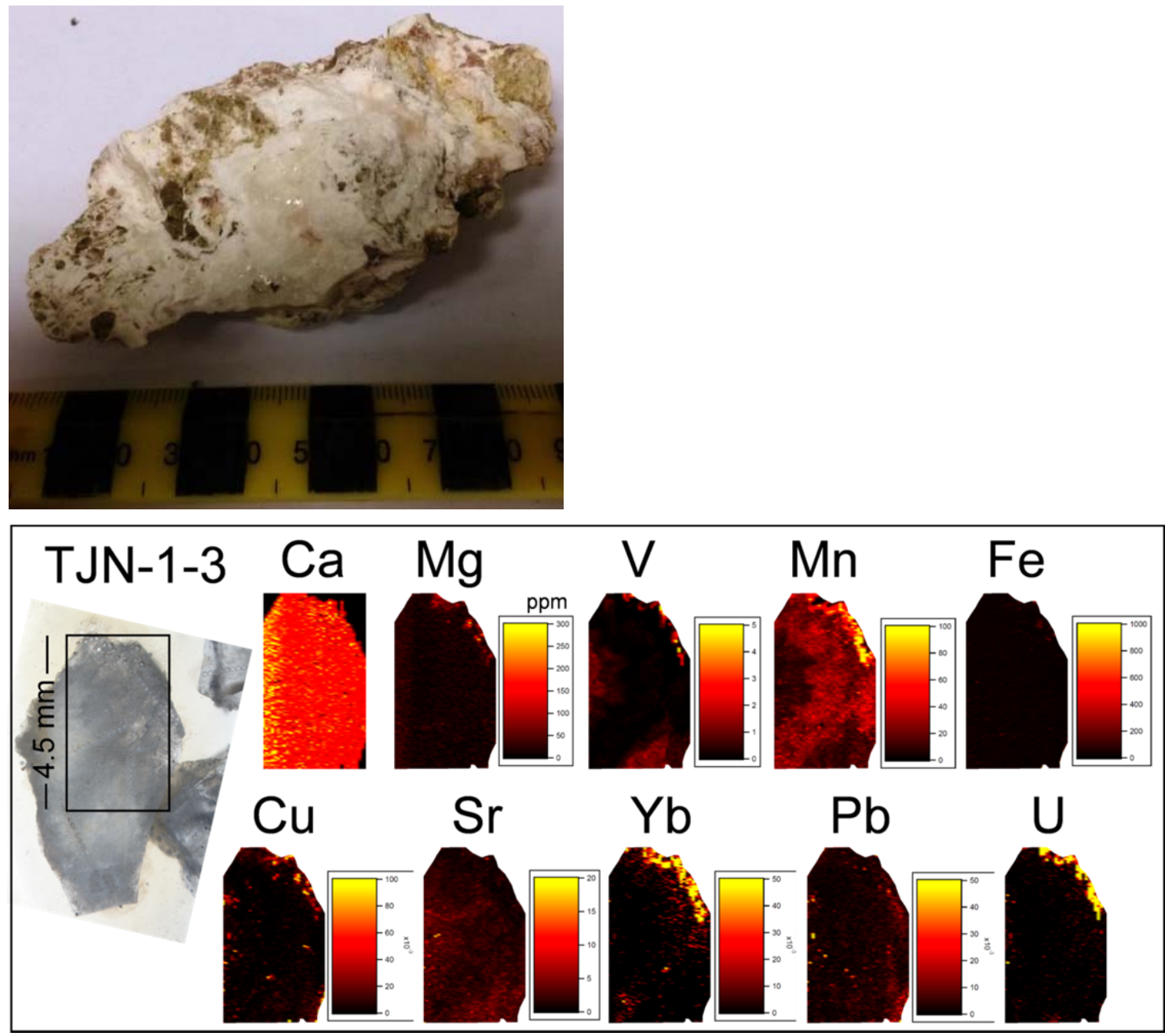
TJN-2-1

Fault:

Set 3

Strike: NE-SW

Dextral oblique slip, unknown displacement (possibly $\sim 80 \mathrm{~m}$ based on ESE-WNW dike offset across Tjornuvik bay), hosted partially within a NE-SW dike. Fault zone comprises mesh of zeolite and calcite crack seal type veins.

\section{Vein sample:}

Crack-seal texture, with uniform planar margins.

Mostly syntaxial zeolite (fibrous) and minor blocky calcite.

Blocky (up to several $\mathrm{mm}$ ) equant calcite grown on final growth band.

Sample taken from latest blocky calcite.

\section{Composition:}

Mapping shows the consistent distribution of uranium compared to other strongly enriched elements (e.g. V, Mn, Sr) . Lead, along with iron and magnesium, is concentrated along cleavage planes. The uranium is inferred to be distributed according to primary zonation, and certainly has not been mobilised differentially.
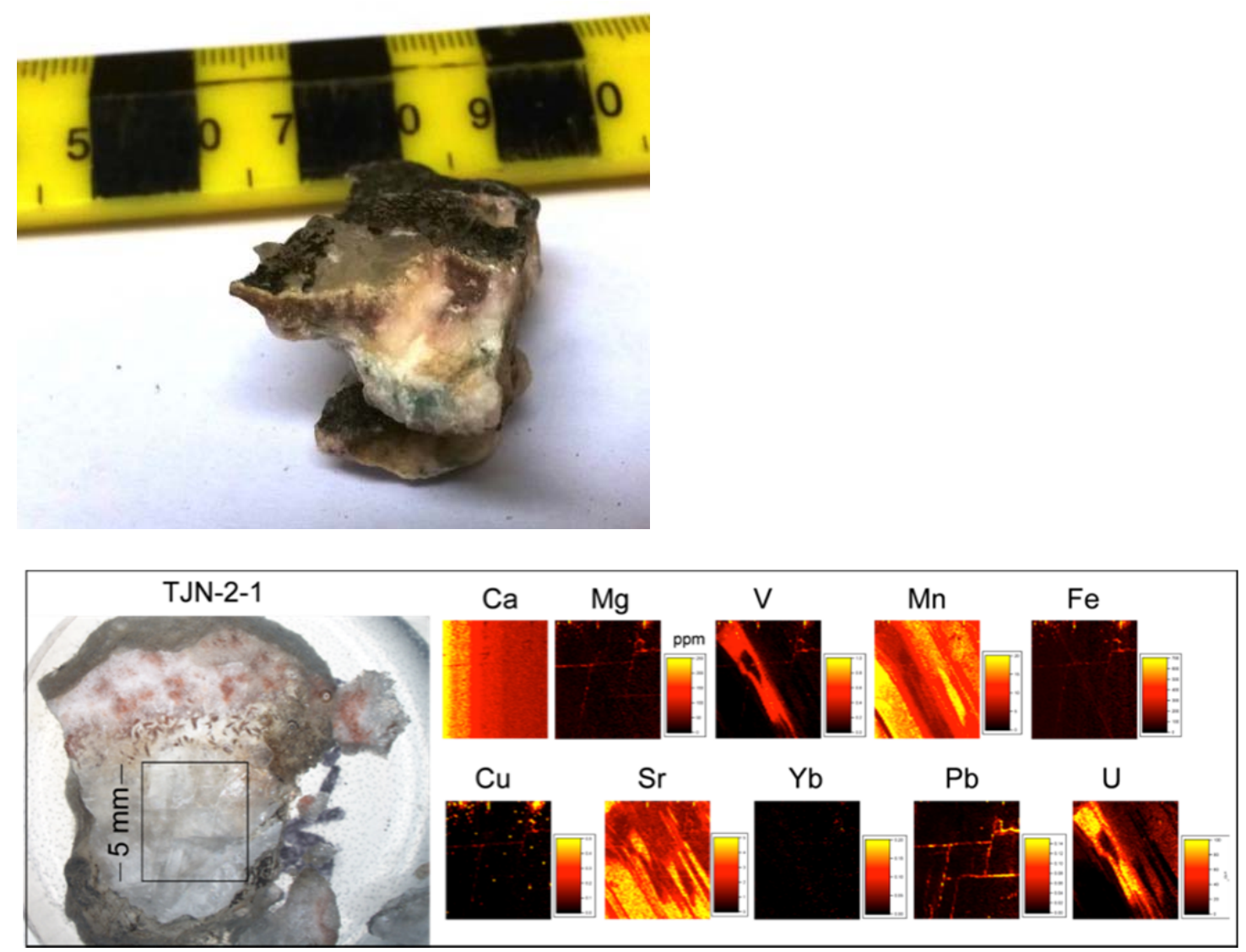


\section{TJN-5-2}

\section{Fault:}

Set 3

Strike: NNE-SSW

Dextral oblique slip, cuts and offsets ESE-WNW dikes. Displacement estimated to be about $20 \mathrm{~m}$ based on dike offset. Fault shows crack seal texture with calcite mineralisation, and local breccia of host rock with calcite fill, up to $20 \mathrm{~cm}$ thick.

\section{Vein sample:}

Probable dilational jog.

Features multi-stage crack-seal syntaxial growth, along with antitaxial growth from fragments of country rock, formed during/after brecciation of country rock during faulting. Later stages feature larger blocky crystals. Minor zeolite along host rock margins is the first formed mineralization.

\section{Composition:}

All elements above detection limits show consistent distribution that is representative of primary growth banding within a blocky calcite crystal.

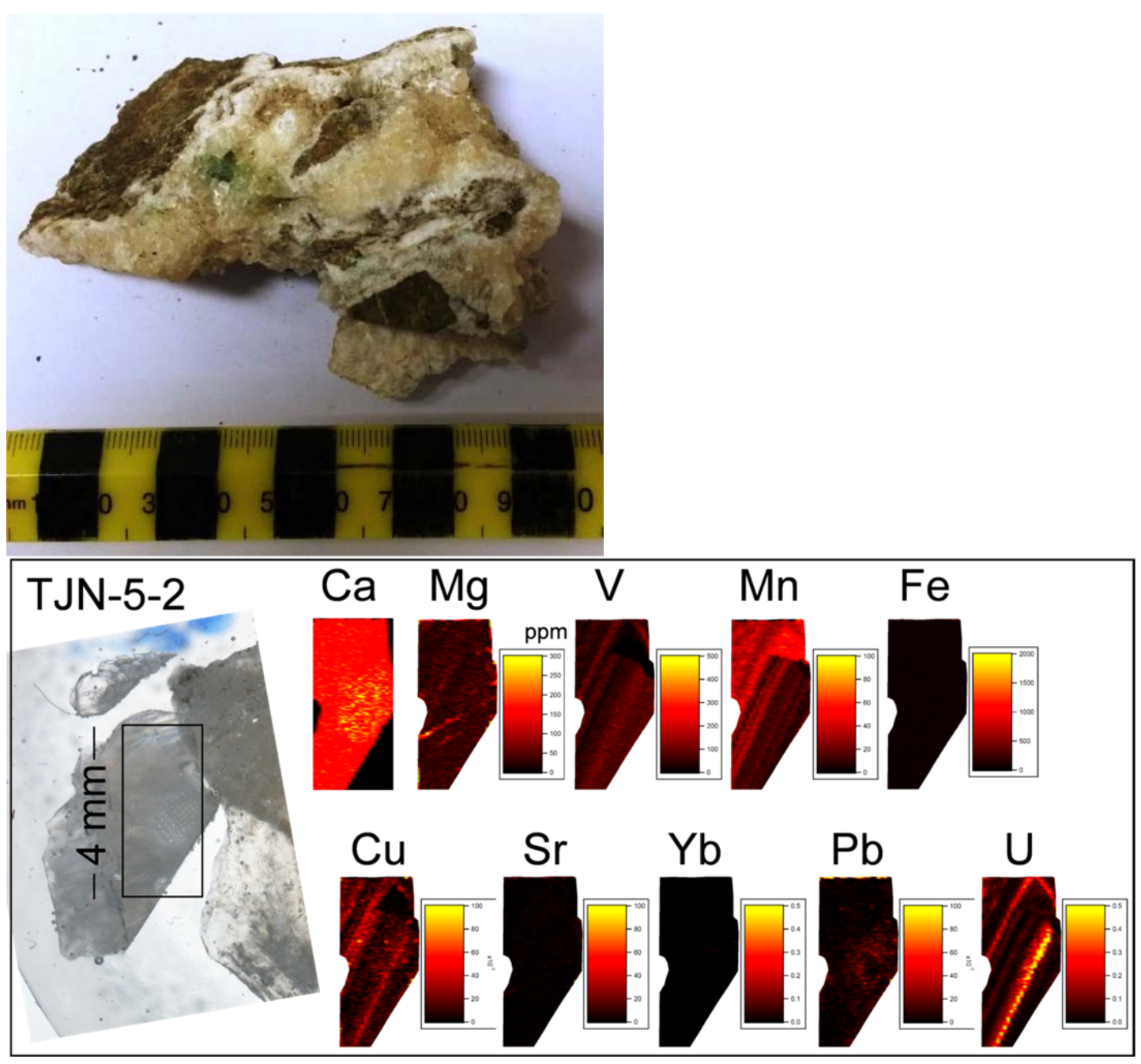




\section{TJN-6-1}

\section{Fault:}

Set 2

Strike: ENE-WSW

Unknown displacement. Directional opening along minor fractures in the damage zone suggests dextral slip. Fault zone comprises a zone of calcite fill, up to $50 \mathrm{~cm}$ thick, which show euhedral calcite growth around 10-20 cm size blocks of basalt host rock. Breccia fragments appear to be selfsupporting across fault thickness, with mineral fill growing radially around blocks. Locally mineralisation is incomplete, showing vugs up to $1-5 \mathrm{~cm}$ across, which display euhedral calcite and zeolite mineralisation on calcite crystal faces.

\section{Vein sample:}

$20-50 \mathrm{~cm}$ wide dilational jog along fault.

Multi-stage crack-seal with several generations of sealing.

Syntaxial calcite growth filling early stages, with blocky to elongate-blocky calcite, and minor zeolite along host margin.

Centre of vein comprises 1 to $10 \mathrm{~cm}$ long calcite crystals that are blocky to elongate, with $1-2 \mathrm{~mm}$ thick zeolite growth along the crystal faces.

Minor scalenohedral calcite forms seen also (several $\mathrm{cm}$ long).

\section{Composition:}

Mapping shows consistent pattern of primary growth zoning across all elements. Minor disturbed zones feature in some elements, and are visible optically. These were avoided for U-Pb analyses.
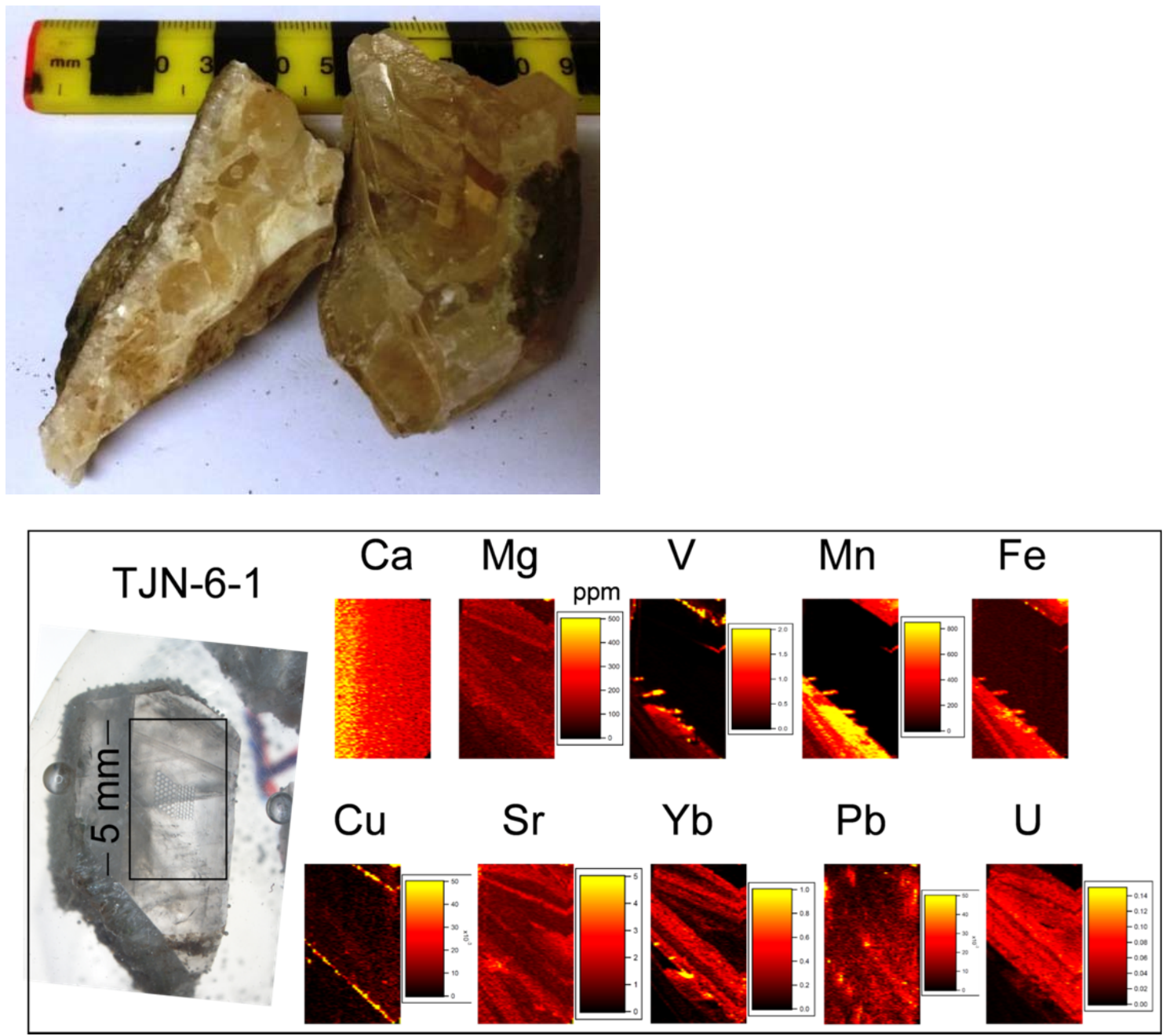


\section{TOR-1-1}

\section{Fault:}

Set 2

Strike: E-W

Dextral oblique-slip fault with 2-5 cm displacement, accommodated across a 2-30 $\mathrm{cm}$ thick fault zone. Fault damage zone comprises minor extension mode fractures, with zeolite mineralisation. Fault core zone displays crack seal type veins of calcite, zeolite, and bitumen. Bitumen staining is observed locally within calcite.

\section{Vein sample:}

Narrow crack-seal vein (10-15mm), with bitumen formed along host margins.

Blocky equant syntaxial calcite growth ( $<3 \mathrm{~mm}$ crystals).

\section{Composition:}

Distribution of elements is consistent across the material, and interpreted as primary growth zoning.

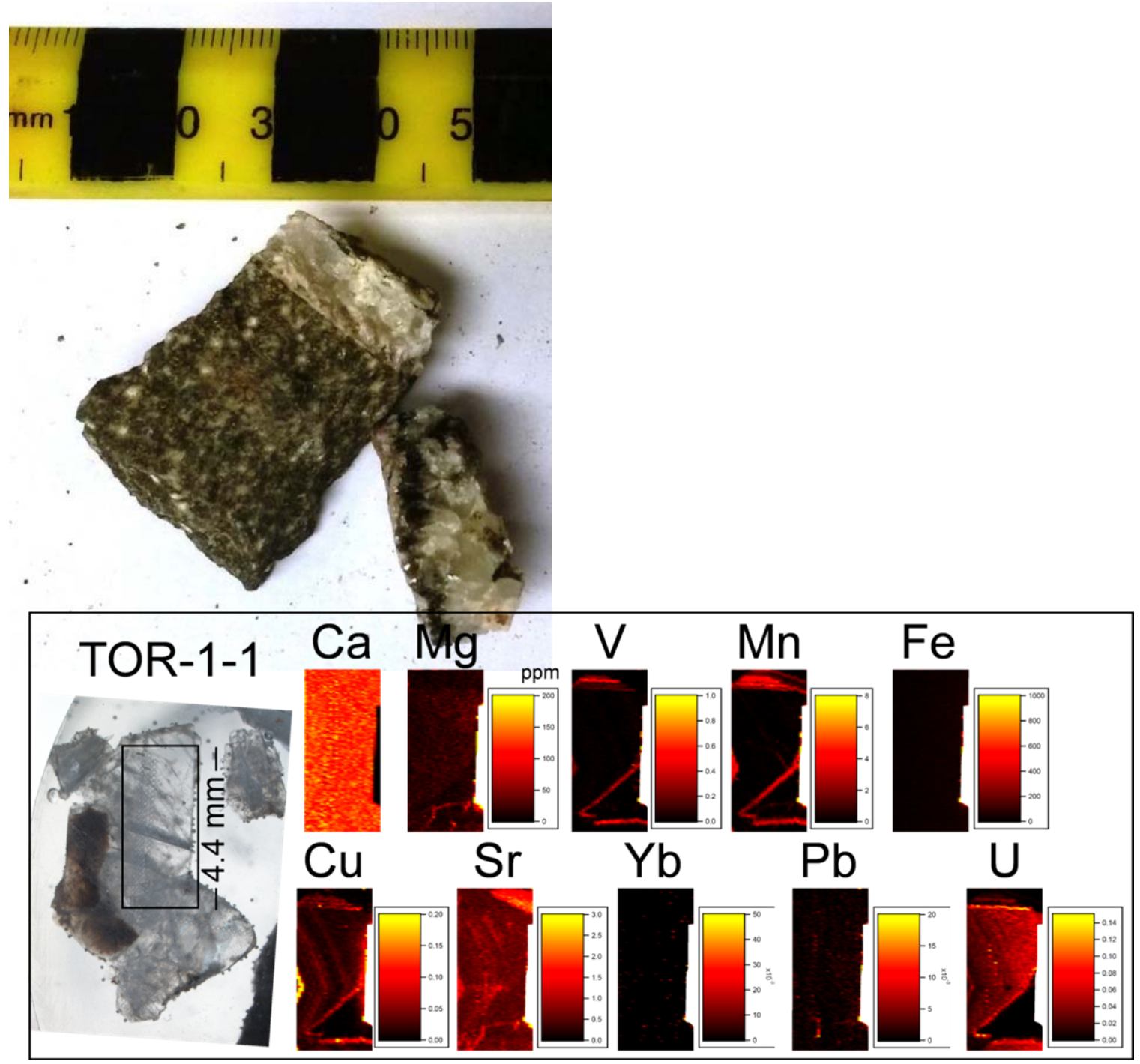


'Unsuccessful' U-Pb dates:

\section{IBO-1-1}

Set 1

Strike: NW-SE

Dip-slip normal fault accommodating 4-5 m displacement. Fault damage forms an asymmetric zone developed preferentially in the fault hanging wall. Principal slip surface shows breccia and cataclasite including variably altered basalt host rock. Cataclasite is cut by a fine fracture mesh that hosts calcite and zeolite mineralisation.

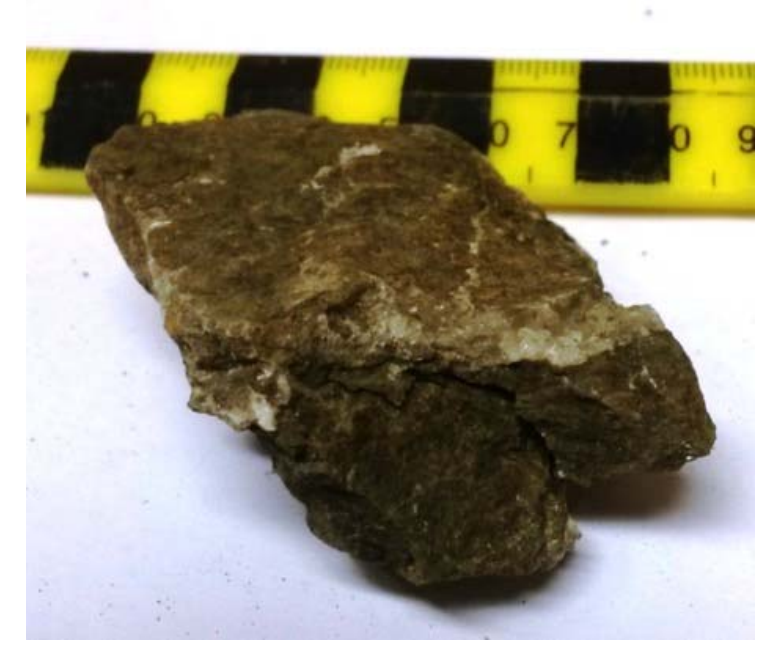

Crack-seal vein in fault core.

Zeolite layers, blocky calcite in middle.

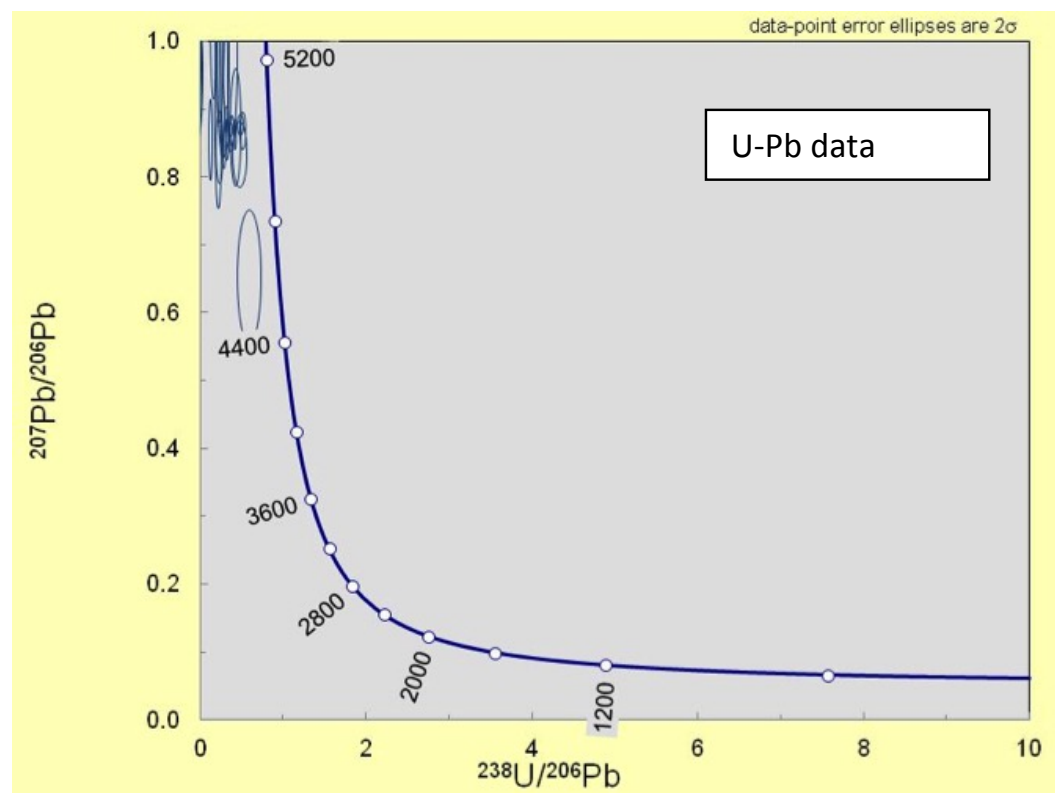

Sample mount 
IBO-2-1

Set 1

Strike: N-S

Dip slip normal fault with $\sim 10 \mathrm{~cm}$ displacement. Fault is developed locally along polygonal cooling fractures, and shows thickening of volcaniclastic sediments in the upper sections of the fault. Fault appears to terminate within the sequence.

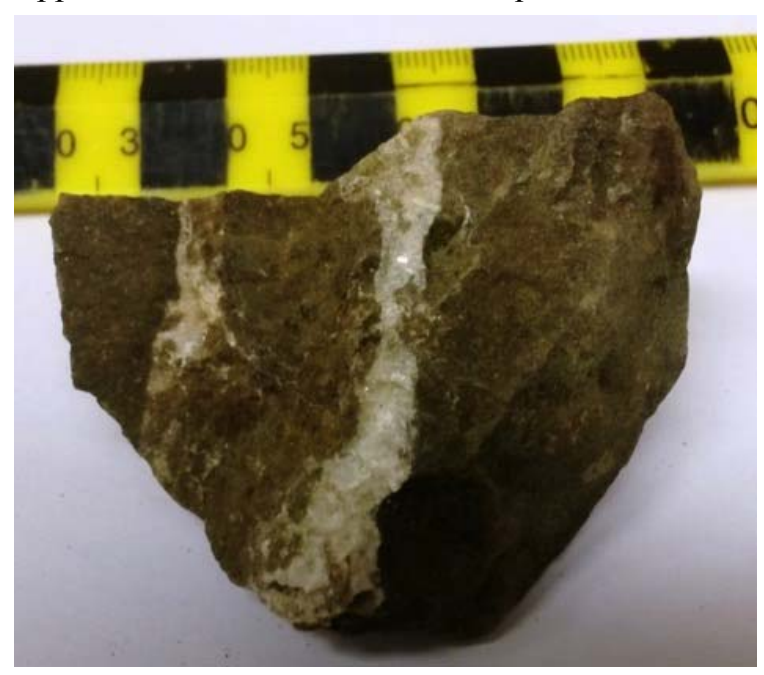

Crack-seal veins

Zeolite layers, blocky calcite in middle
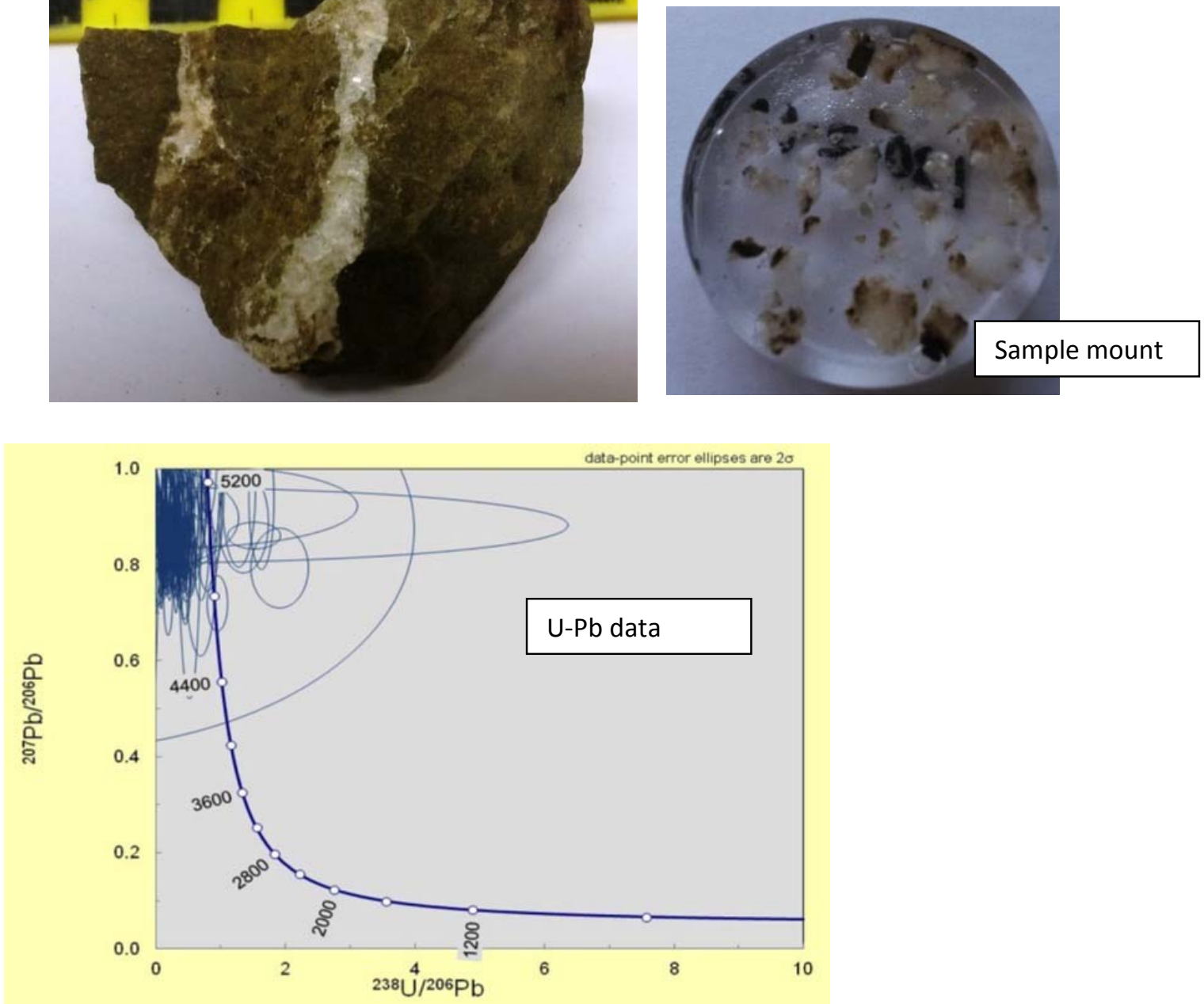
HOV-1-1

Set 1

Strike: N-S

Dip slip normal fault with $\sim 1 \mathrm{~m}$ displacement accommodated across a $2 \mathrm{~m}$ thick zone of crack seal type veins, and local dilational jog.

Crack-seal + fill

$1-2 \mathrm{~mm}$ zeolite rim on basalt margin.

Some brecciation of host rock.

$1-5 \mathrm{~mm}$ blocky calcite. Multiple generations, based on surfaces though mineralised veins.

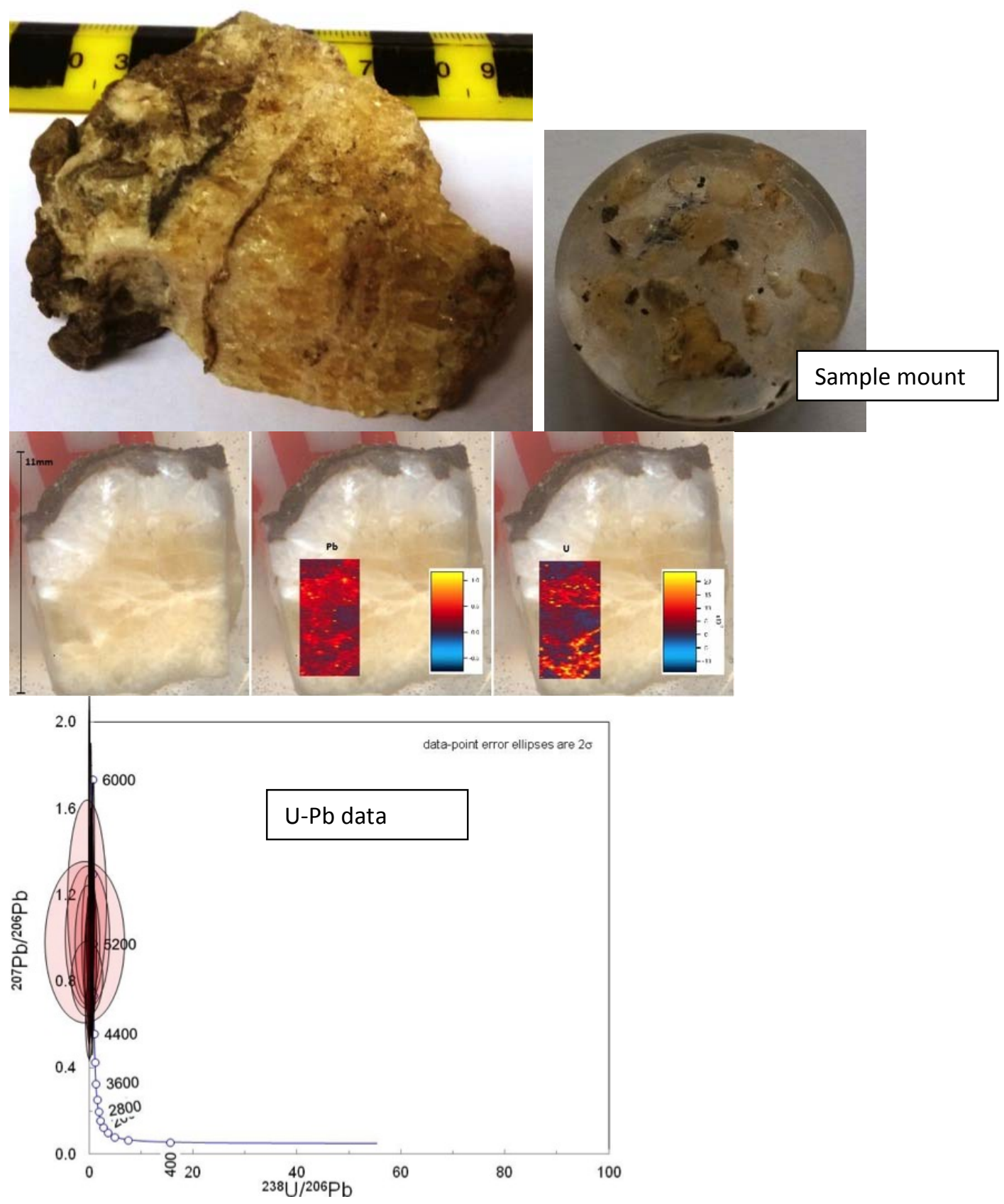


Sel-1-1

Set 2

Strike: WNW-ESE

Major strike slip fault zone (?), up to $10 \mathrm{~m}$ thick. Fault zone comprises lens of breccia and cataclasite that strike at an angle to the main fault. Calcite and zeolite mineralisation is brecciated into the fault zone, and cross cuts oblique shear fabric at a low angle (i.e. sub-parallel to the fault).

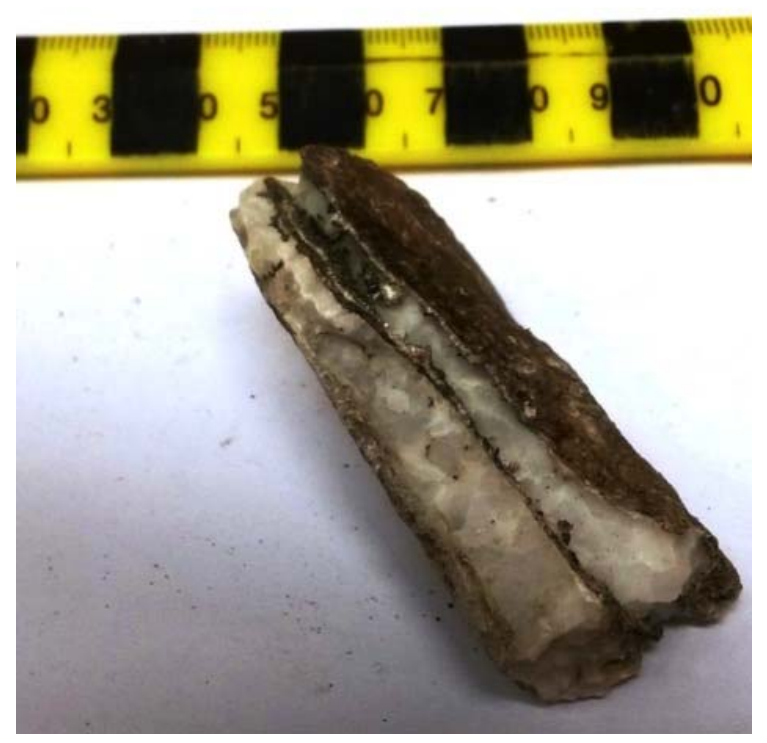

Principal slip zone margin crack seal.

Large blocky calcite equant crystals, minor zeolite layers on rim.

$2-10 \mathrm{~m}$ crystals
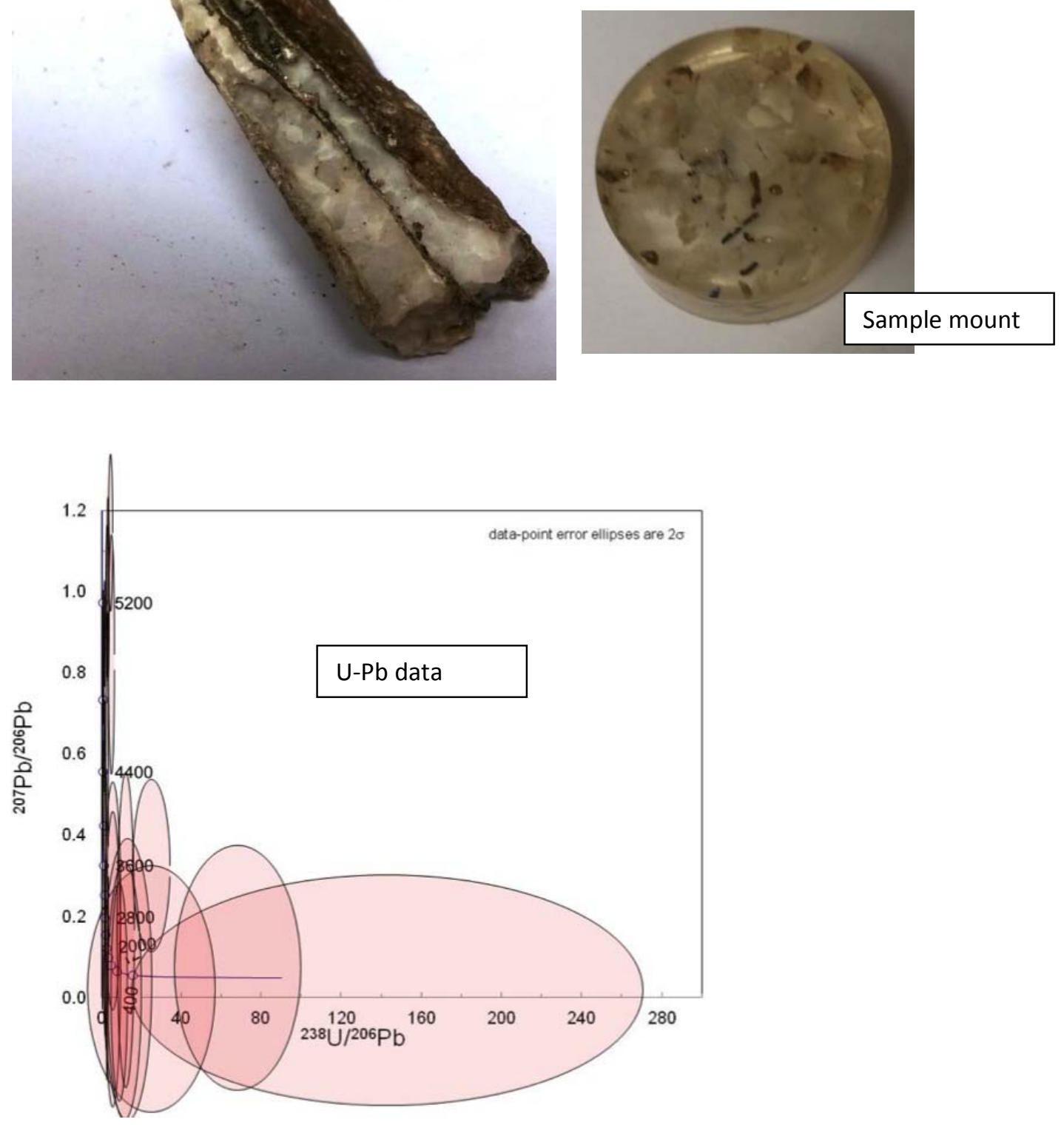


\section{Sel-1-2}

Set 2

Strike: WNW-ESE

Same fault zone as SEL-1-1.

Oblique vein network.

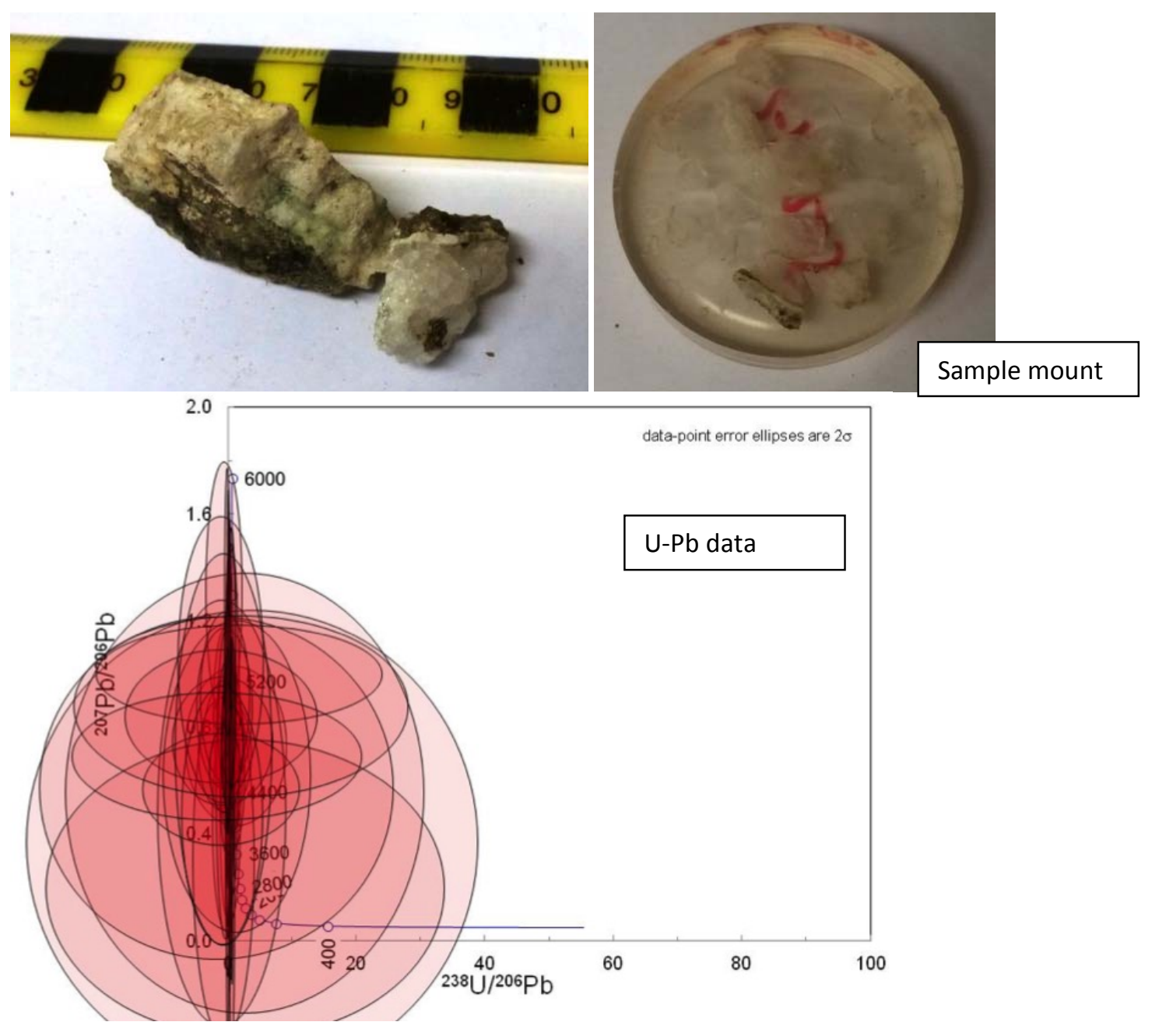




\section{Ley-1-1}

Set 2

Strike: WNW-ESE

Dike-hosted strike-slip fault zone with unknown displacement. Fault zone is up to $4 \mathrm{~m}$ thick locally, with well defined damage zone of crackle breccias, and a fault core comprising mosaic and chaotic breccias. Crack seal veins forming the fault core margin are locally brecciated into the principal slip zone.
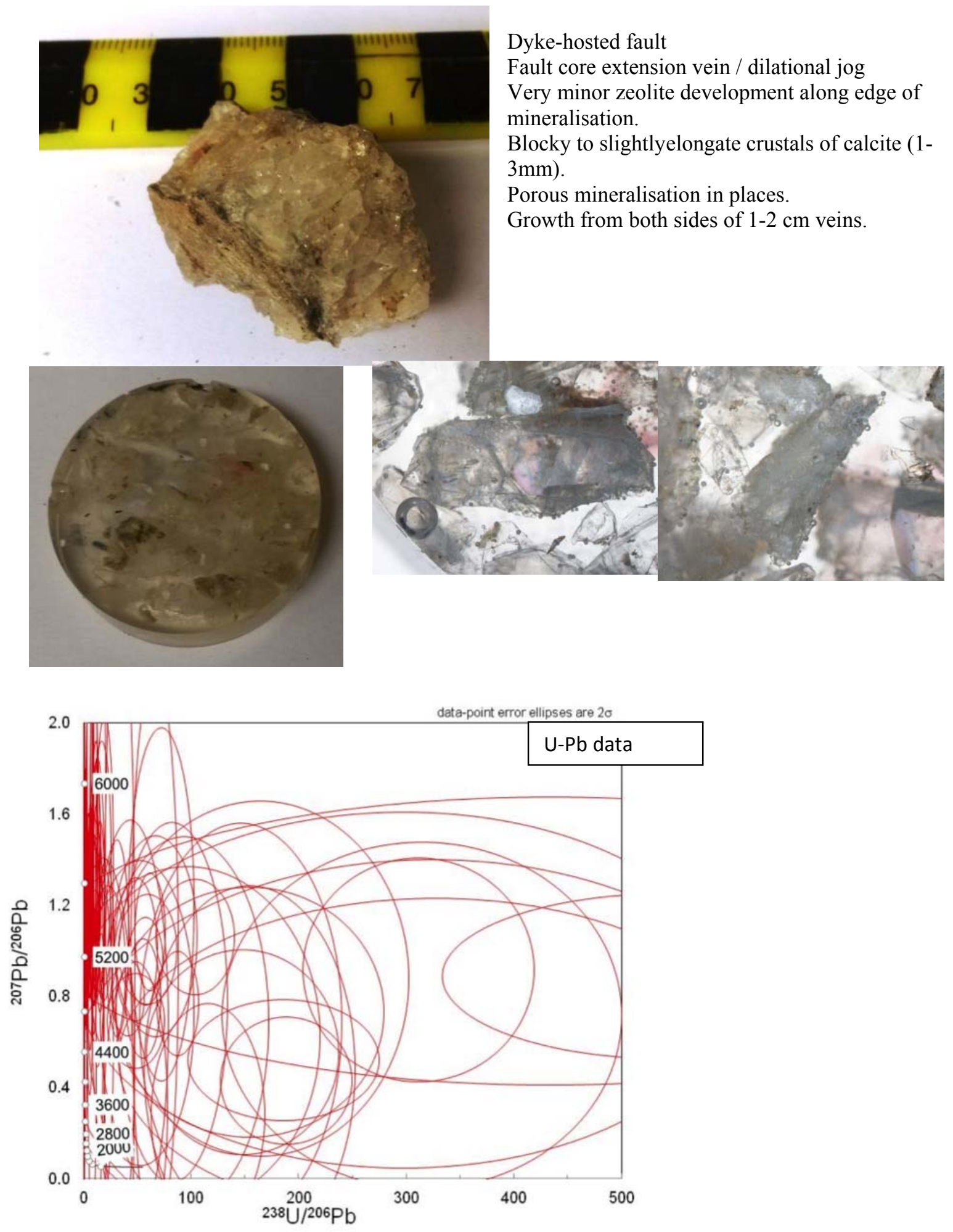


\section{GOT-1-1}

Set 2

Strike: WNW-ESE

Potential major strike slip fault. Fault zone comprises fault core up to $3 \mathrm{~m}$ thick, and damage zone $>10$ $\mathrm{m}$ thick. Fault core comprises lenses of intensely deformed host rock and calcite and zeolite mineral veins. Principal slip surface displays cataclasites and foliated cataclasites. Calcite and zeolite mineralisation is observed along the fault core in various forms, from intact crack seal veins and dilational jogs, to brecciated vein fragments.

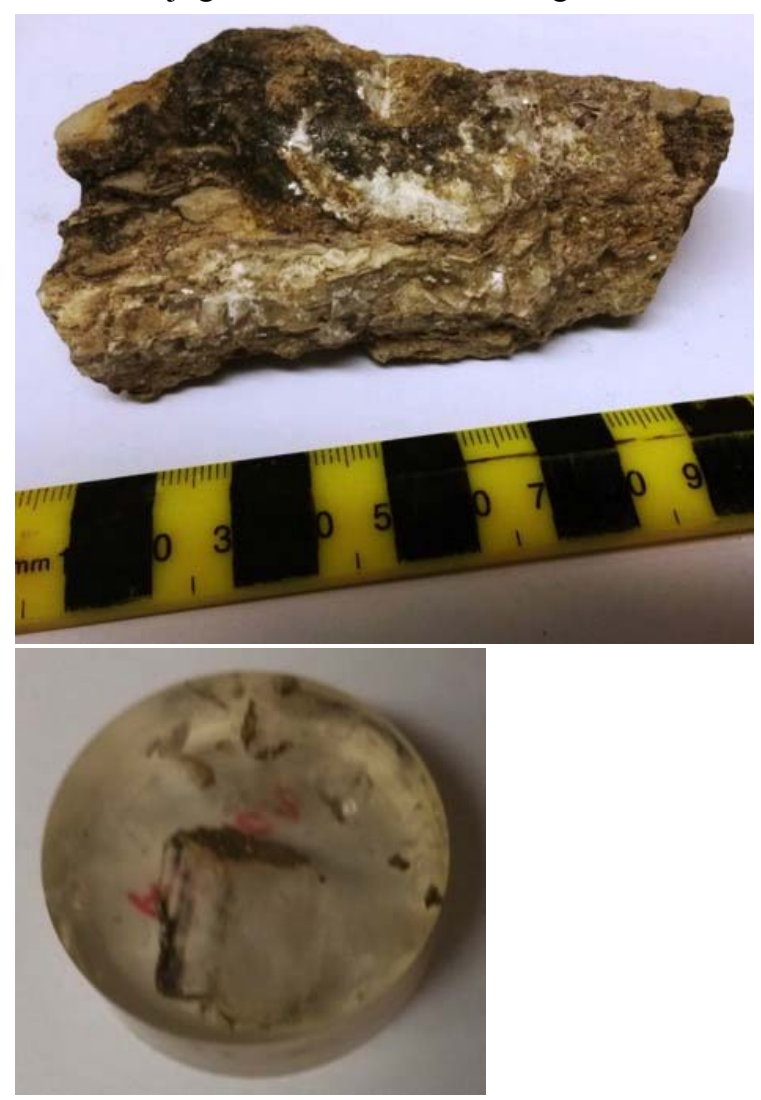

Dilational jogs , crack seal. Hosted in cataclasite. Large $2-15 \mathrm{~mm}$ blocky equant calcite, very minor zeolite.

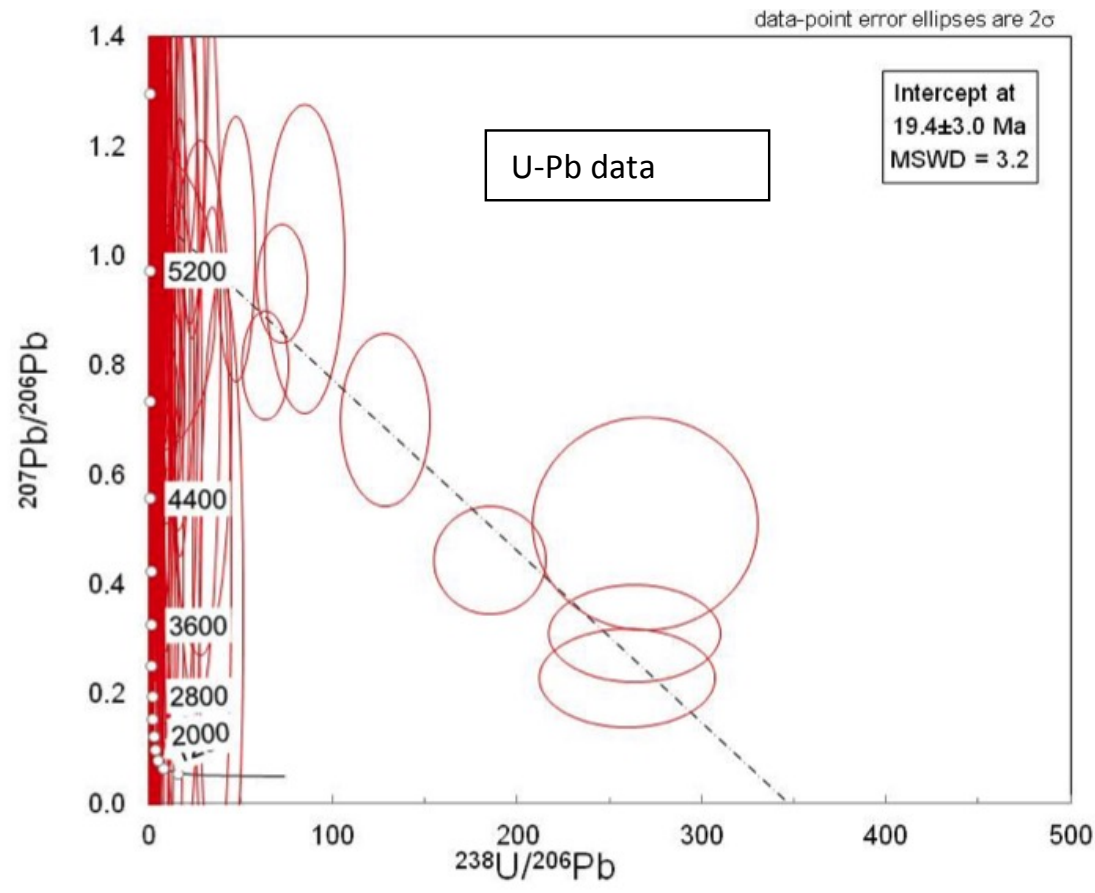


TJN-1-2

Set 2

Strike: WNW-ESE

Same fault as TJN-1-3
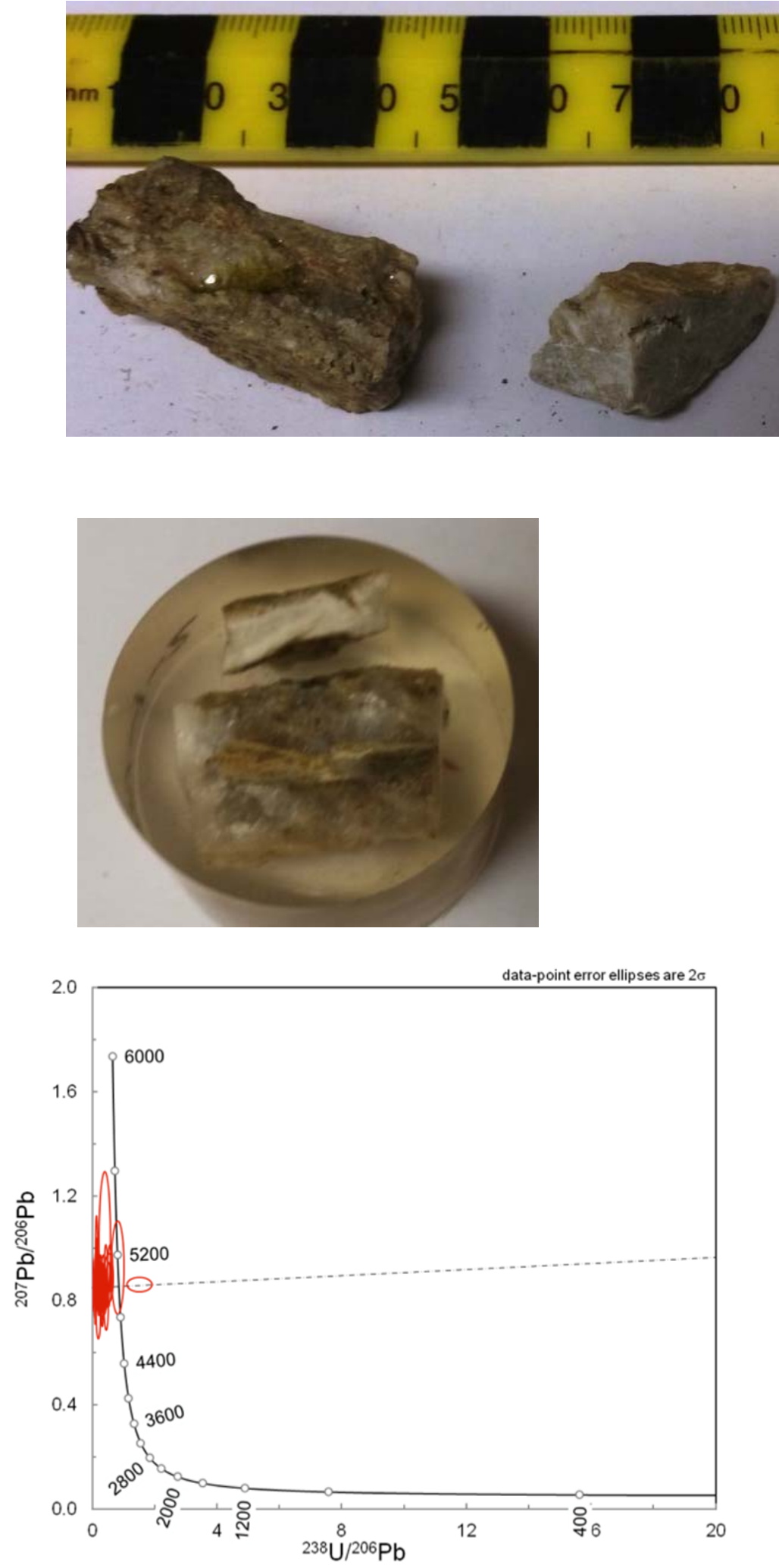

Dyke-hosted.

Crack-seal.

Mixed zeolite-calcite vein with blocky calcite. 


\section{References:}

Coogan, L.A., Parrish, R.R. and Roberts, N.M., 2016. Early hydrothermal carbon uptake by the upper oceanic crust: Insight from in situ U-Pb dating. Geology, v. 44, p.147-150.

Jochum, K.P., Weis, U., Stoll, B., Kuzmin, D., Yang, Q., Raczek, I., Jacob, D.E., Stracke, A., Birbaum, K., Frick, D.A. and Günther, D., 2011. Determination of reference values for NIST SRM 610-617 glasses following ISO guidelines. Geostandards and Geoanalytical Research, v. 35, p.397429.

Li, Q., Parrish, R.R., Horstwood, M.S.A. and McArthur, J.M., 2014. U-Pb dating of cements in Mesozoic ammonites. Chemical Geology, v. 376, p.76-83.

Spencer, C.J., Roberts, N.M., Cawood, P.A., Hawkesworth, C.J., Prave, A.R., Antonini, A.S. and Horstwood, M.S., 2014. Intermontane basins and bimodal volcanism at the onset of the Sveconorwegian Orogeny, southern Norway. Precambrian Research, v. 252, p.107-118.

Woodhead, J.D. and Hergt, J.M., 2001. Strontium, neodymium and lead isotope analyses of NIST glass certified reference materials: SRM 610, 612, 614. Geostandards Newsletter, v. 25, p.261-266. 


\section{Analytical Conditions:}

\begin{tabular}{|c|c|}
\hline \multicolumn{2}{|c|}{ Laboratory \& Sample Preparation } \\
\hline Laboratory name & Geochronology \& Tracers Facility, NERC Isotope Geosciences Laboratory \\
\hline Sample type/mineral & Calcite \\
\hline Sample preparation & Chips mounted in 1 inch epoxy mounts \\
\hline Imaging & Cold-stage cathodoluminesce on some samples \\
\hline \multicolumn{2}{|l|}{ Laser ablation system } \\
\hline Make, Model \& type & ESI/New Wave Research, UP193UC \\
\hline Ablation cell \& volume & NWR TV2 \\
\hline $\begin{array}{l}\text { Laser wavelength } \\
(\mathrm{nm})\end{array}$ & $193 n m$ \\
\hline Pulse width (ns) & $4 \mathrm{~ns}$ \\
\hline Fluence $\left(\mathrm{J} . \mathrm{cm}^{-2}\right)$ & $\sim 7 \mathrm{~J} / \mathrm{cm}^{-2}$ \\
\hline Repetition rate $(\mathrm{Hz})$ & $10 \mathrm{~Hz}$ \\
\hline Spot size $(\mu \mathrm{m})$ & $100 \mu \mathrm{m}$ \\
\hline $\begin{array}{l}\text { Sampling mode / } \\
\text { pattern }\end{array}$ & Static spot \\
\hline Carrier gas & $\begin{array}{l}100 \% \mathrm{He} \text {, Ar make-up gas from DSN-100 combined using a Y-piece } 50 \% \\
\text { along sample line. }\end{array}$ \\
\hline $\begin{array}{l}\text { Ablation duration } \\
\text { (secs) }\end{array}$ & 30 secs \\
\hline $\begin{array}{l}\text { Cell carrier gas flow } \\
(1 / \mathrm{min})\end{array}$ & $0.61 / \mathrm{min}$ \\
\hline \multicolumn{2}{|l|}{ ICP-MS Instrument } \\
\hline Make, Model \& type & Nu Instruments, Attom, SC-ICP-MS \\
\hline Sample introduction & Ablation aerosol \\
\hline RF power (W) & $1300 \mathrm{~W}$ \\
\hline Make-up gas flow & $0.71 / \mathrm{min} \mathrm{Ar}$ \\
\hline Detection system & Single Mascom SEM \\
\hline Masses measured & $202,204,206,207,208,232,238$ \\
\hline Integration time per & Dwell times of $200 \mu$ s to $1000 \mu s$ per peak \\
\hline
\end{tabular}




\begin{tabular}{|c|c|}
\hline peak (ms) & \\
\hline $\begin{array}{l}\text { Total integration time } \\
\text { per reading (secs) }\end{array}$ & $\begin{array}{l}0.35 \mathrm{sec} \\
\text { (should represent the time resolution of the data) }\end{array}$ \\
\hline $\begin{array}{l}\text { Sensitvity / Efficiency } \\
\text { (\%, element) }\end{array}$ & $\sim 0.2 \% \mathrm{U}$ \\
\hline IC Dead time (ns) & $15 \mathrm{~ns}$ \\
\hline \multicolumn{2}{|l|}{ Data Processing } \\
\hline Gas blank & 30 second on-peak zero subtracted \\
\hline Calibration strategy & See text. \\
\hline $\begin{array}{l}\text { Reference Material } \\
\text { info }\end{array}$ & See text. \\
\hline $\begin{array}{l}\text { Data processing } \\
\text { package used / } \\
\text { Correction for LIEF }\end{array}$ & $\begin{array}{l}\text { In-house spreadsheet data processing after initial signal integration } \\
\text { using Nu Instruments TRA software. No LIEF correction (mean of } \\
\text { uncorrected ratios used). }\end{array}$ \\
\hline Mass discrimination & Standard sample bracketing \\
\hline $\begin{array}{l}\text { Common-Pb } \\
\text { correction, } \\
\text { composition and } \\
\text { uncertainty }\end{array}$ & $\begin{array}{l}\text { None applied. Ages calculated from regressions used in Tera- } \\
\text { Wasserburg plots. }\end{array}$ \\
\hline $\begin{array}{l}\text { Uncertainty level \& } \\
\text { propagation }\end{array}$ & $\begin{array}{l}\text { Ages are quoted at } 2 \text { sigma absolute, propagation is by quadratic } \\
\text { addition. Excess variance of reference material propagated into sample } \\
\text { data. Systematic uncertainties include age uncertainty of reference } \\
\text { material. }\end{array}$ \\
\hline \multicolumn{2}{|l|}{ Other information } \\
\hline
\end{tabular}




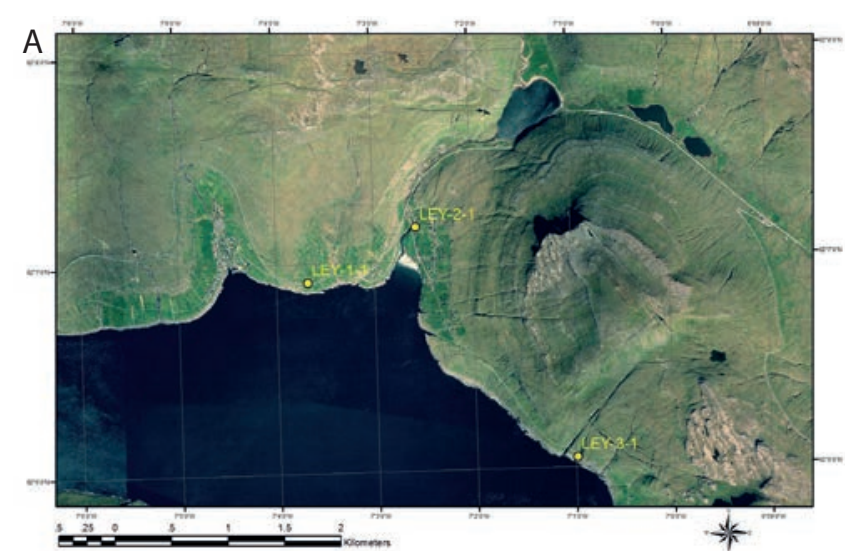

LEY-1-1: 703'40.462"W 6206'54.736"N
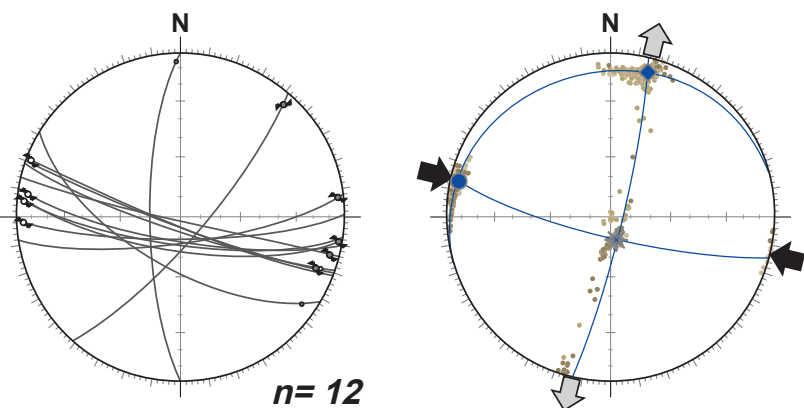

- extension vein
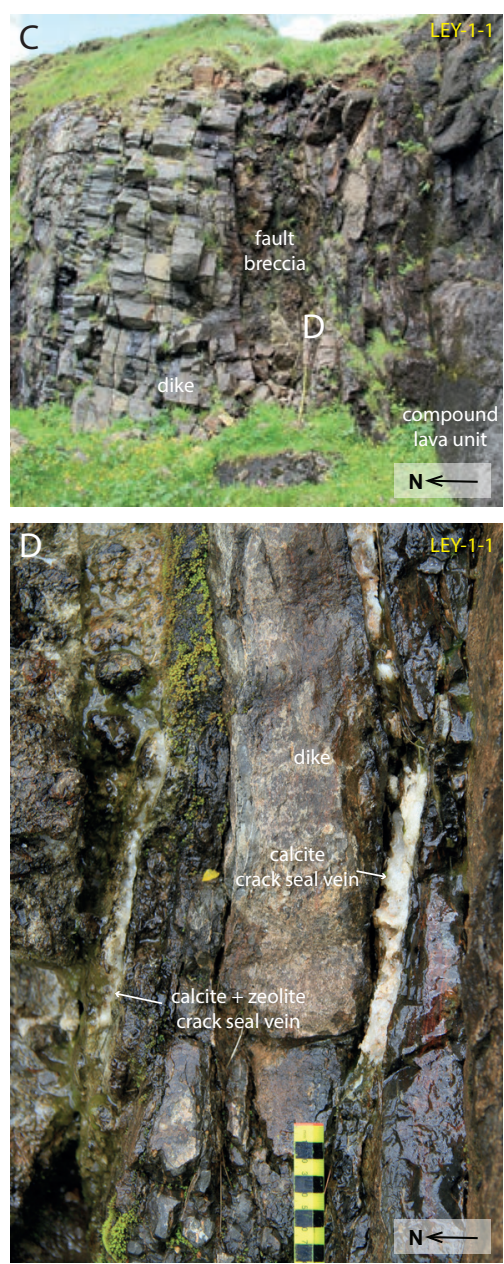

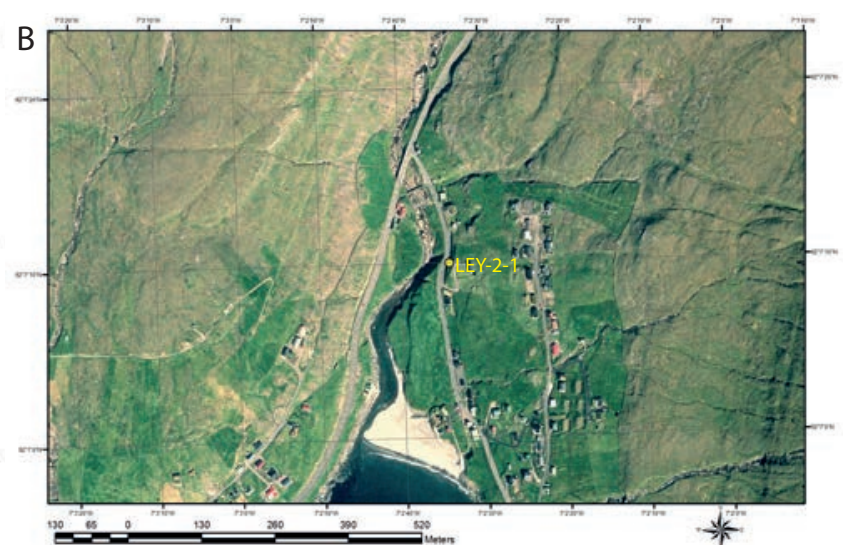

LEY-2-1: 702'31.278' W 62 6'63.314"N
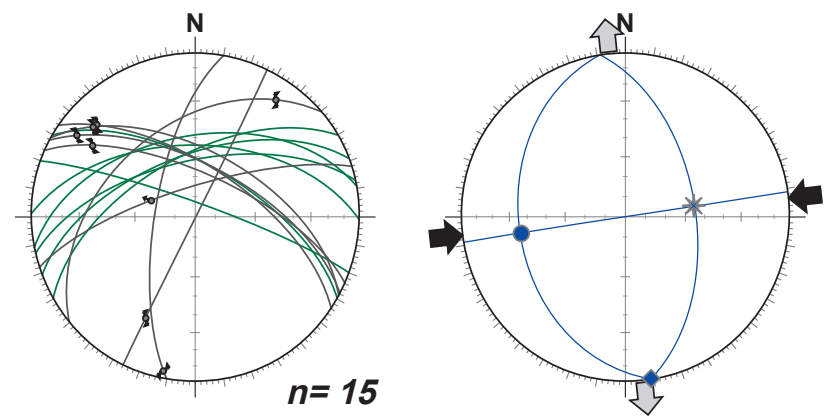

$\Rightarrow>$ max. horizontal contraction

- *

$\Leftrightarrow \Rightarrow$ max. horizontal extension
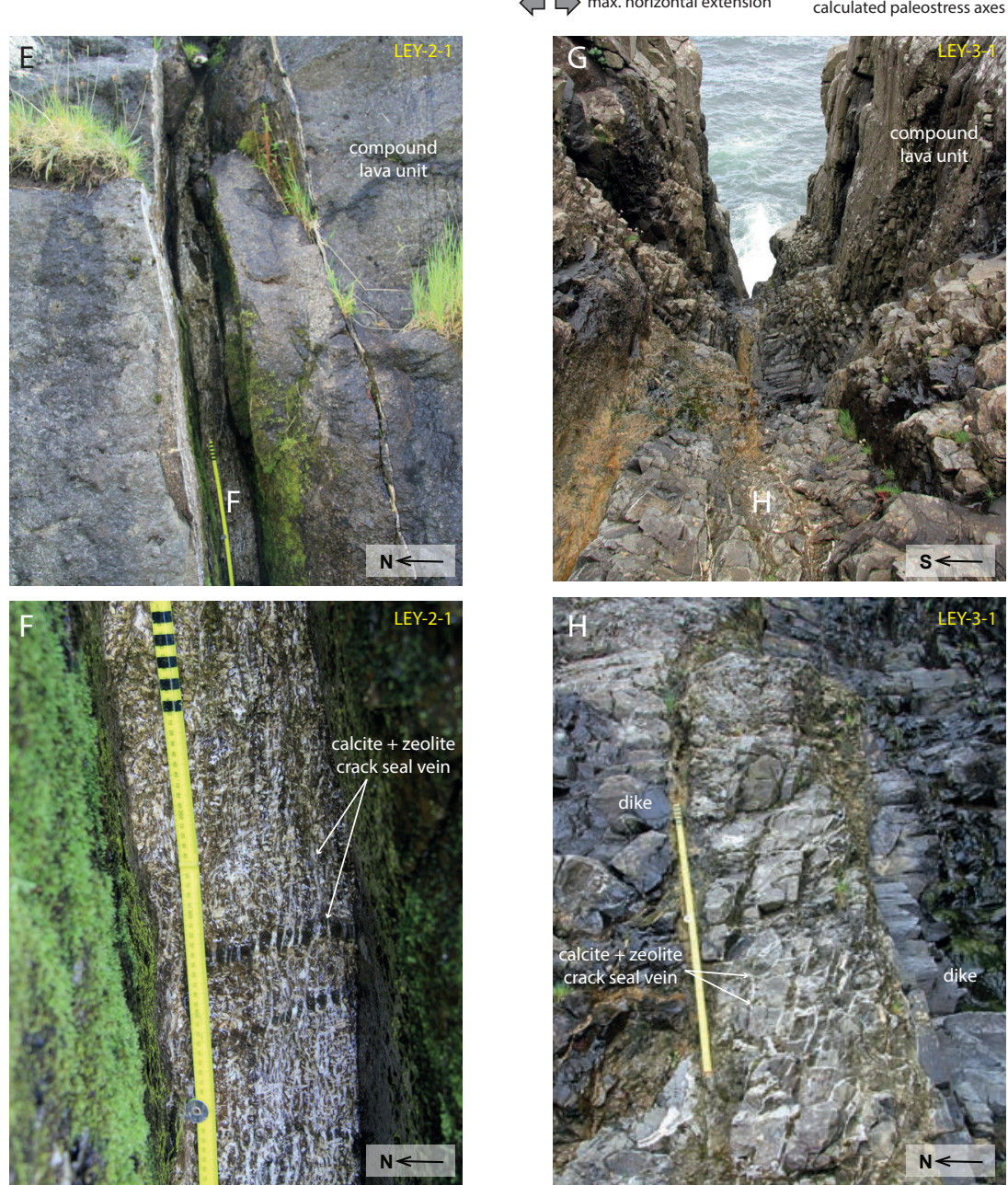
Supplementary Figure

MOL \& TOR samples
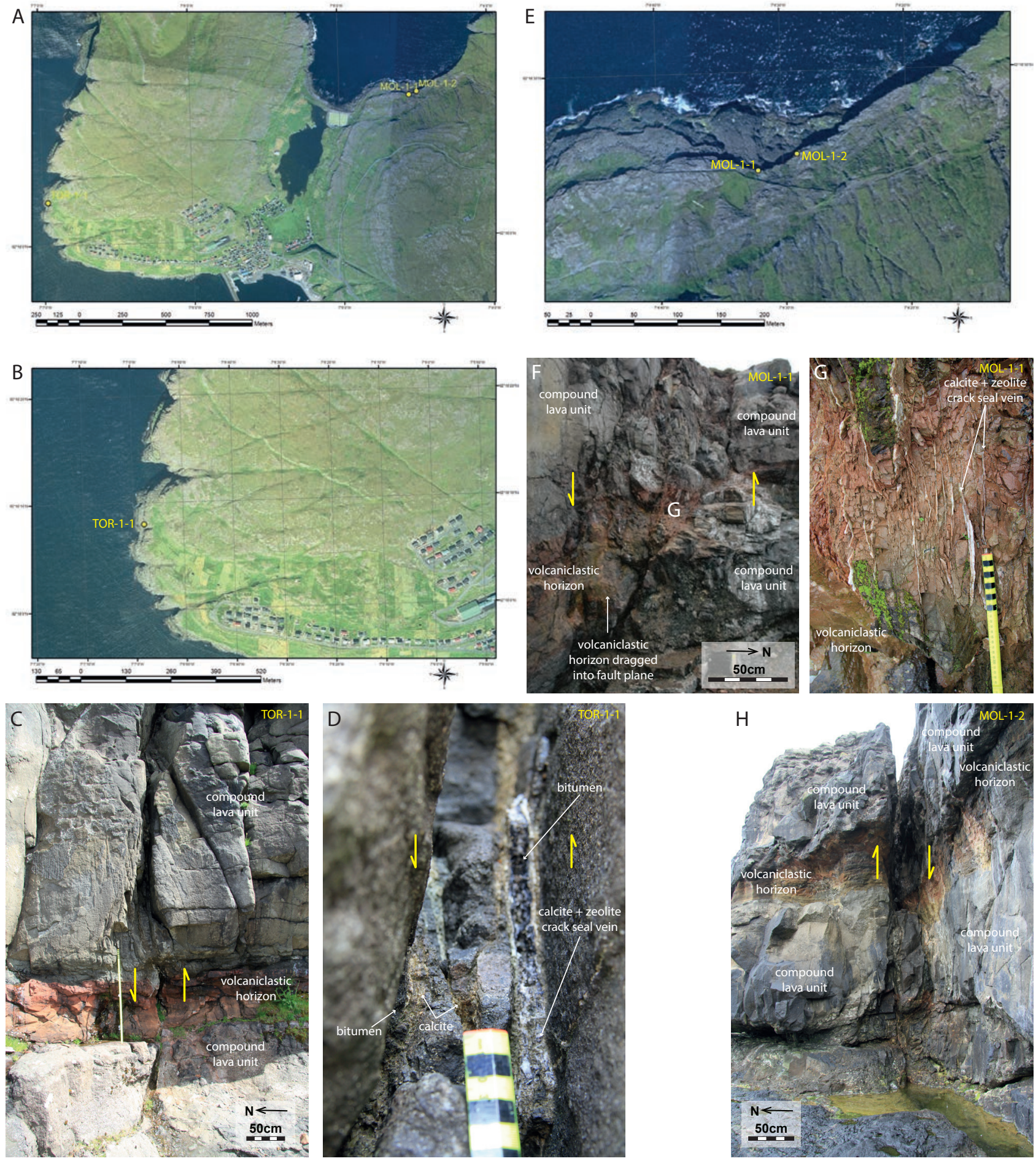

Eidi peninsula (TOR-1-1; MOL-1-1; MOL-1-2): 704'29.959' W 62'18'28.778' N
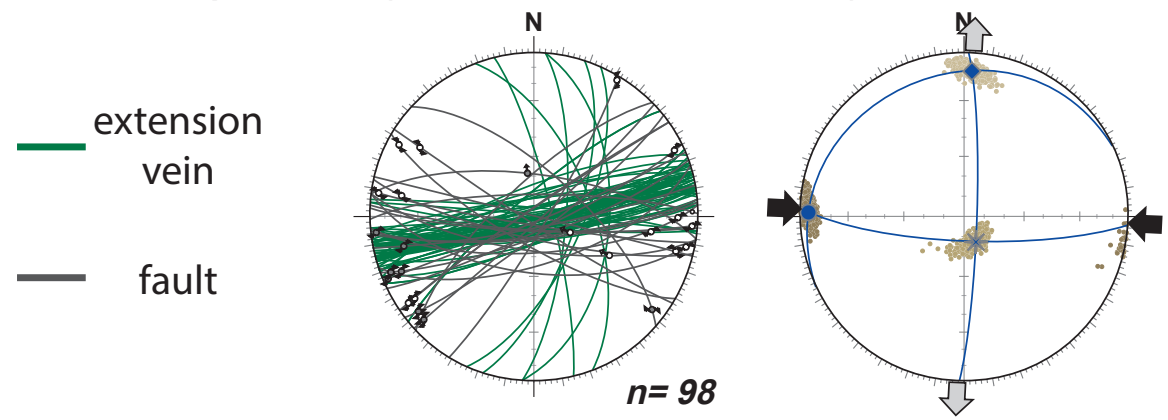

$\Rightarrow$ max. horizontal contraction

\ $\Rightarrow$ max. horizontal extension

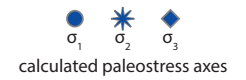



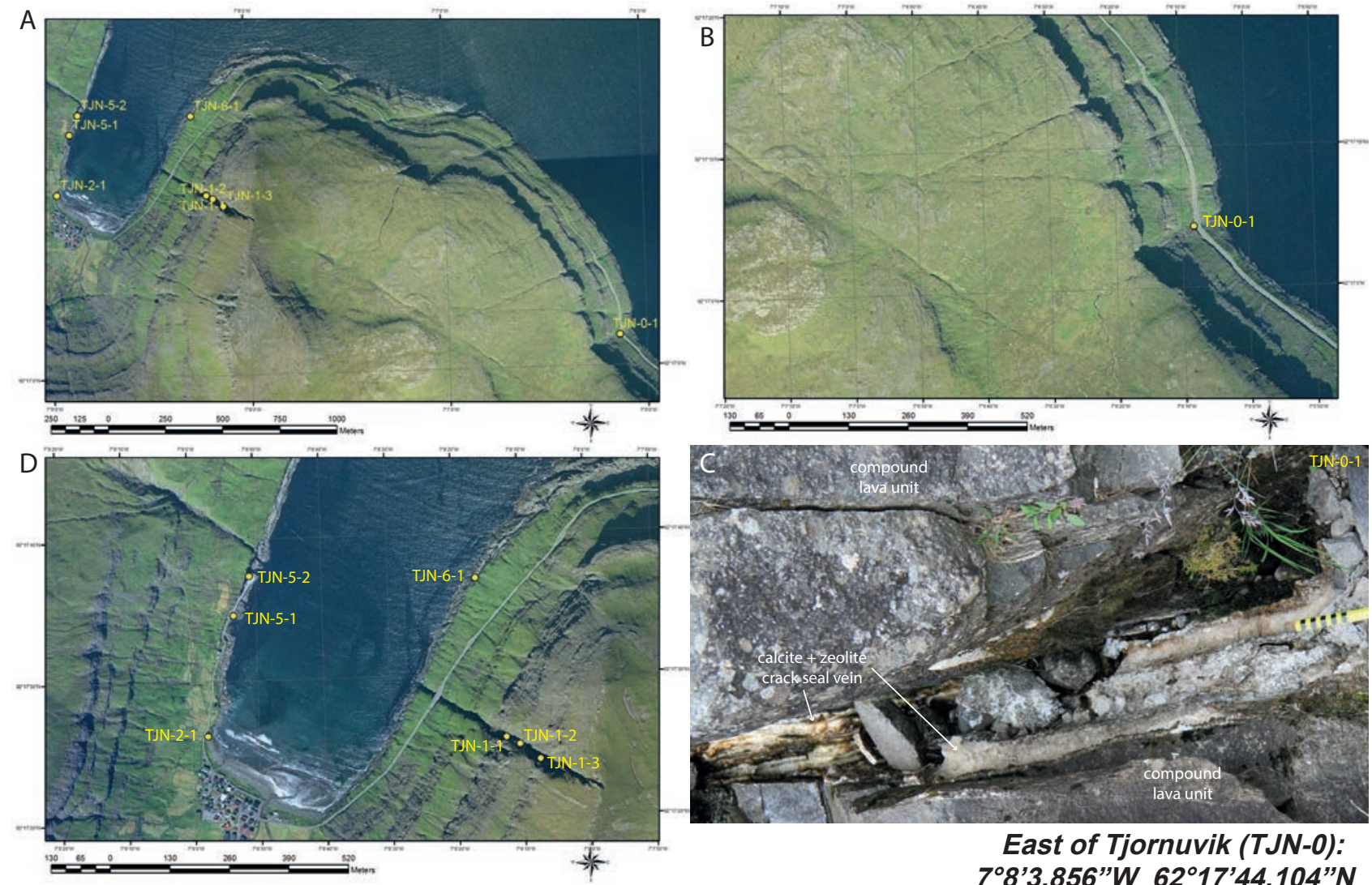

East of Tjornuvik (TJN-0):
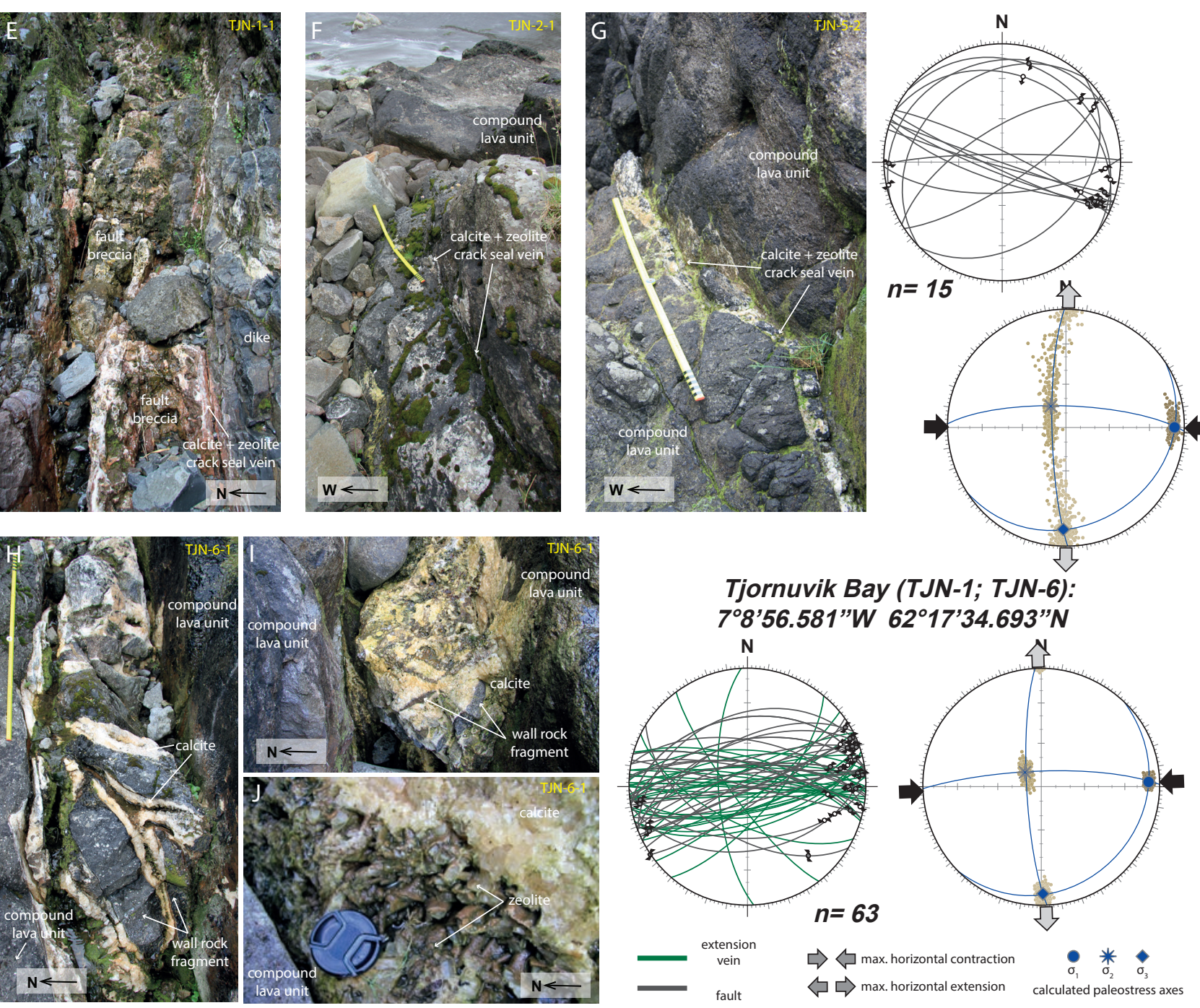